IZA DP No. 5128

Explaining the Labour Market Outcomes of First, Second and Third Generation Immigrants in Canada

Jiong Tu

August 2010 


\title{
Explaining the Labour Market Outcomes of First, Second and Third Generation Immigrants in Canada
}

\author{
Jiong Tu \\ Human Resources and Skills Development Canada - Labour Program \\ and IZA
}

\section{Discussion Paper No. 5128 \\ August 2010}

\author{
IZA \\ P.O. Box 7240 \\ 53072 Bonn \\ Germany \\ Phone: +49-228-3894-0 \\ Fax: +49-228-3894-180 \\ E-mail: iza@iza.org
}

Any opinions expressed here are those of the author(s) and not those of IZA. Research published in this series may include views on policy, but the institute itself takes no institutional policy positions.

The Institute for the Study of Labor (IZA) in Bonn is a local and virtual international research center and a place of communication between science, politics and business. IZA is an independent nonprofit organization supported by Deutsche Post Foundation. The center is associated with the University of Bonn and offers a stimulating research environment through its international network, workshops and conferences, data service, project support, research visits and doctoral program. IZA engages in (i) original and internationally competitive research in all fields of labor economics, (ii) development of policy concepts, and (iii) dissemination of research results and concepts to the interested public.

IZA Discussion Papers often represent preliminary work and are circulated to encourage discussion. Citation of such a paper should account for its provisional character. A revised version may be available directly from the author. 


\section{ABSTRACT \\ Explaining the Labour Market Outcomes of First, Second and Third Generation Immigrants in Canada}

This paper examines the effectiveness of Canadian immigration policy by analyzing the differences in the returns to education between first, second and third generation immigrant men. Regression results indicate that the second generation with high school education and lower do not earn significantly less than the equally educated third generation. However, the second generation with at least postsecondary education experience a wage deficit to the third generation. I explain the well-educated second generation's difficulty in translating their intellectual ability into productivity by their ethnic and linguistic distance from the Canadian mainstream, and by a negative city-specific effect. Regression results using sub-samples categorized by subsequently interacting educational attainments with ethnicity, mother tongue and city of residence support these explanations. I then suggest that assimilation policies targeting the well-educated first and second generation immigrants be designed to promote the acceptance of their human capital by the Canadian labour market.

JEL Classification: F22, J15, J31, J62

Keywords: immigrant, second generation, wages, education, ethnicity, Canada

Corresponding author:

Jiong Tu

Research and Data Development

Human Resources and Skills Development Canada - Labour Program

165 Hotel de Ville

Gatineau, QC K1A0J2

Canada

E-mail: jtu@lakeheadu.ca 


\section{$1 \quad$ Introduction}

In the big picture of labour market performance of immigrants in Canada, the portrait of the second generation is often vague. Due to an absence of suitable dataset that includes a generation identifier, the quantity of economic research on the second generation is limited. Most studies focus on the first generation's income assimilation only, such as Baker and Benjamin (1994) and Aydemir and Skuterud (2005). They have unanimously found that immigrants cannot catch up in earnings with the native-born. However, if assimilation is treated as a multi-generational process, the labour market outcome of the second generation is a key measure of the success of an immigrant family. Therefore, it is important to distinguish the second generation and analyze how they fare differently in the Canadian labour market from the other generations.

On the one hand, the second generation are different from the first generation in that the former are born in Canada. Unlike their foreign born parents, the second generation obtain the majority or even full education and work experience in North America. Therefore, they are expected to perform better in the labour market than the first generation whose foreign education and experience are often poorly recognized in the host country (Schaafsman and Sweetman, 2001 and Aydemir and Skuterud, 2005). On the other hand, the second generation are different from the third generation in that at least one of their parents is born abroad. The intergenerational earnings mobility discovered by Aydemir, Chen and Corak (2005) may reflect the foreign born parents' influence on the second generation's labour market outcomes.

In a recent study, Aydemir and Sweetman (2006) use the 2001 Canadian Census to find that second generation immigrants in Canada have better socio-economic characteristics than the third generation. However, when their advantages in these characteristics are accounted for, the second generation earn less than the third generation on average. They attribute the second generation's earnings deficit to the lower returns to their observable characteristics, particularly, years of schooling. However, they do not examine whether the cross-generation differences in returns vary with educational levels, because the linearity of years of schooling variable in their regressions restricts the returns to education to be the same at every level of education. Moreover, they do not explain the reason for the second generation's returns to education, despite the fact that 
the second generation mainly receive the same type of education as the third generation.

In this paper I complement the literature by the following two contributions: (a) I examine how the second generation's disadvantage to the third generation in terms of returns to education varies at different levels of educational attainment. This is important as it helps policies makers identify targeted population. Limited public resources should be allocated to people who truly need support, and immigrant groups who have not yet achieved wage parity with the third generation, ceteris paribus, should be the focus of assimilation policy. (b) I explain the cross-generation differences in the returns to education by ethnicity, language and place of residence. This is because the return to education largely depends on the transferability of knowledge acquired from the school into productivity, which may be affected by the cultural and linguistic distance between immigrants and Canadian mainstream. If the relatively low return to the second generation's education is due to a low proficiency in one of the official languages, assimilation policy should aim at increasing the language skills among those people. However, if it is their ethnic and cultural diversity that causes the cross-generation differences, policy should then emphasize on accelerating the social acceptance of immigrants from countries that are culturally distant from Canada and, at the same time, promoting these immigrants' understanding of the Canadian routines.

An additional question is the heterogeneity within the second generation due to their parents' place of birth. An immigrant's marriage to a native may be a signal of acculturation and assimilation (the causal relationship of intermarriage and income is not the focus of this study though). Meng and Gregory (2005) use Australian censuses to show that intermarried immigrants earn more than those who marry other immigrants. If the former pass their ability of adaptation on to their offspring through generic and family channels, the second generation with only one foreign born parent may fare better than those with both parents born abroad. This hypothesis is empirically tested by Rooth and Ekberg (2003) using Swedish data. However, no Canadian literature has ever made a direct comparison between these two second generation groups. In order to fill the knowledge gap, I also test for the heterogeneity within the second generation in terms of their wages.

Another relevant, yet less-studied, group of immigrants are the first generation 
who migrate as non-adults. Being brought to Canada at a young age, they are likely to acquire their highest education and work experience in the host country. Additionally, the priority in linguistic and cultural adjustment also accelerates young immigrants' integration into the mainstream. Schaafsman and Sweetman (2001) show that immigrant relative earnings are negatively associated with their age at immigration, using the 1986, 1991 and 1996 Censuses. Young immigrants' earnings premium is attributed to their fast acculturation rate and the low return to adult immigrants' foreign education and experience. These reasons are also used by Chiswick and DebBurman (2004) to explain the labour market outcome of young immigrants in the US. In light of these findings, I will also test the hypothesis that immigrants who migrate before school age perform as well as the second generation, due to their similarity in the family composition and Canadian background.

In this paper, I use the 2001 Canadian Census for my empirical analysis, because it contains, for the first time since 1971, information about an individual's generation status as well as his or her parents' places of birth. Multivariate regression results show that young immigrants who migrate before age 20 earn as much wages as the second generation at each educational level, and that the wage differential is statistically insignificant between the second generation with one foreign born parent and those with both parents born abroad. Among males with at least postsecondary education, the third generation outperform the first and second generation. Their wage premium over other generations can be explained by ethnicity, mother tongue and area of residence.

The paper proceeds as follows. Section 4.2 surveys literature on cross- generation comparison of and intergenerational mobility in immigrant labour market performance. In section 4.3, I compare different generation groups using descriptive statistics from the 2001 Canadian Census. Section 4.4 introduces the multivariate regression method in and discusses the estimation results. In section 4.5, I use more detailed regressions on sub-samples to analyze the wage differentials across ethnicity, mother tongue and geographic area groups. Finally, section 4.6 concludes.

\section{Literature on Cross-Generation Analysis}

Besides Canada, the cross-generation wage differentials are also studied using 
data from other countries. Aydemir and Sweetman (2006) compare the three generations in the US to those in Canada, given the differences in immigration policy and immigrant place of origin in the two countries. Unlike Canadian immigrants, the second generation and young first generation in the US do not earn significantly different from the third generation, no matter whether education, ethnicity and location are controlled for. In a study for Australia, Chiswick and Miller (1985) find that the second generation earn more than the average, but the earnings premium disappears when observable characteristics are accounted for. However, in either study, the reasons for the similarity or difference in the earnings between the second and third generations are not fully explored.

One school of researchers use intergenerational earnings mobility models to explain the second generation's labour market performance. The method was developed by Borjas (1992 and 1993) and Solon (1992) in an attempt to link the second generation to their potential foreign-born parents by pooling two datasets collected twenty or thirty years apart. Since there is no "family identifier" that can match a first generation immigrant who is observed in an earlier data set to his child who is observed in another data set a few decades later, the first generation samples then have to be aggregated by ethnicity and geographic area, and the means of their education and earnings enter the regression function of the second generation's earnings. Using data from the US censuses, Borjas (1993) finds that the correlation in earnings between the first and second generations is strong during 1940-1990. He suggests that one explanation may be the “ethnic capital” that is passed from fathers to sons. Solon's (1992) finding using survey data is similar to Borjas's in that the intergenerational earnings mobility is very low from 1968 to 1985.

Card, DiNardo and Estes (2000) apply a similar method on the 1940 and 1970 censuses and the 1994-1996 Current Population Surveys, but they find stronger evidence for intergenerational earnings mobility through the channel of education. In other words, children of immigrants with higher education tend to be better educated and hence have higher earnings. Caponi (2009) complements the argument on the linkage between the first and second generations using samples of Mexican immigrants in the US. He finds that the "altruistic" first generation immigrants are positively self-selected: Mexicans with more human capital are more likely to migrate, and they are able to transfer their 
manual and intellectual abilities to their children. Therefore, the second generation are expected to acquire more education and to perform better in the US labour market than their parents.

Similar research has been conducted using European data. In Netherlands, van Ours and Veenman (2003) find that low educational attainment persists from the first generation to the second generation immigrants. Rooth and Ekberg (2003) suggest that the poor labour market outcome by the second generation in Sweden is associated with their ethnic parents. Additionally, they notice the heterogeneity within the second generation: those with one foreign-born parent perform better than those having both parents born abroad. Nicoletti and Ermisch (2008) find that the intergenerational earnings mobility in the UK is constant over those born in the 1950s and 1960s.

In Canada, Aydemir, Chen and Corak (2005) combine the 1981 and 2001 Canadian Censuses to estimate the degree of intergenerational earnings mobility. Although they find that paternal earnings are strongly associated with the second generation's years of schooling, the low return to their education reduces the degree of persistence in earnings between fathers and children. The generational mobility in earnings is therefore higher among immigrants in Canada than those in the US.

However, these studies on intergenerational mobility are mostly subject to a selection bias due to the lack of an accurate match of parents and children; for example, if the least successful immigrants return to their home country and the remaining second generation are from relatively better off families, the estimated intergenerational earnings persistence then may be downward biased against the true value.

\section{Data and Descriptive Statistics}

The dataset that I use in this study is the 2001 Census of Canada Public Use Microdata File, because it provides information on an individual's generation status and his or her parents' place of birth. By definition, the first generation refers to persons born outside Canada; the second generation refers to those who were born in Canada and had at least one parent born abroad; and the third generation and over refers to those who were born in Canada and whose parents were also born in Canada.

In addition, with the availability of information on age-at-immigration in census, I 
am able to identify young immigrants who arrive at different stages of schooling ages (preschool, elementary and high school) because receiving early education in the host country may play an important role in a person's future labour market performance.

Combining variables of generation status and immigrants' age at immigration, I am able to divide the sample into the following eight groups. ${ }^{1}$

Canadian born:

Third generation and over

Second generation, father is foreign born

Second generation, mother is foreign born

Second generation, both parents are foreign born

Foreign born:

First generation, age at immigration 0-4

First generation, age at immigration 5-12

First generation, age at immigration 13-19

First generation, age at immigration $>20$

The cross-sectional census data satisfies the econometric requirements of this study, because my purpose is to identify and explain wage differentials between the young first generation, the second, and third generations at a point of time, whereas earnings assimilation of adult first generation immigrants is not the focus.

My sample is restricted to non-aboriginal males in primary working ages, that is, 25-54 years old. I use annual income from wages and salaries to measure a person's labour market performance because it captures variations in both the unit income (say, weekly wage) and labour supply (weeks worked in a year). For a meaningful calculation of the logarithm of wages, I subsequently drop observations with zero wages which account for about 16 percent of the sample. Income from self-employment is not included, because it may be negative due to a business loss.

As to the level of education, according to Ferrer and Riddell (2008), it is the completion of an educational program, rather than the time spent in school, that rewards an individual with earnings premium. Thus, educational attainment is a more appropriate measure of educational outcome than years of schooling, and it is therefore used in my

1 The categorization is similar to Aydemir, Chen and Corak (2005) and Aydemir and Sweetman (2006), but I include more age-at-immigration groups. 
regression models.

I report the statistical summary for Canadian born and foreign born men in Table 1. Compared to the third generation, the second generation with one foreign born parent, either father or mother, are well educated. Their share of high school dropouts is 6 percentage points lower than the third generation, whereas the share of above university degree is 6 percentage points higher. The second generation whose parents are both born abroad are younger than any other groups on average. However, their share of university degree holders is even higher than the second generation with one foreign born parent.

Among the foreign born males who migrate as non-adults, the educational attainment seems to be negatively correlated with the age at immigration. For example, teenage immigrants have the highest high school dropout rate, whereas their proportion of postgraduate is the lowest. The education distribution of immigrants who migrate before age 4 is similar to that of the second generation. Adult immigrants who migrate after twenty years old are likely the principle applicants or their spouses, and they have by far the highest share of postgraduate degree holders.

One distinction between the second generation with one foreign born parent and those with two foreign born parents is mother tongue. About 64 percent of the latter speak English or French as their mother tongue, whereas the share for the former is as high as 93 percent (even higher than the third generation). For the foreign born, the share of mother tongue that is an official language declines with the person's age of migration.

Another evidence of heterogeneity among the second generation is the proportion of visible minority. The vast majority of second generation with one foreign born parent are white. Given the closeness of white immigrants to traditional Canadians in terms of cultural background and language spoken, it is reasonable to believe that their offspring are very similar to native-born Canadians. By contrast, the share of visible minority is more than 10 percent for the second generation whose parents are both foreign born. Among immigrants, the proportion of visible minority increases with age of migration. This suggests that, at least 25 years before the census year (that is, 1976 and earlier), more white immigrants than non-whites landed in Canada with kids or gave birth to children after their arrival.

The first and second generations' geographic distribution is very different from 
the third: more than 30 percent immigrants and second generation with two foreign born parents choose to live in the Census Metropolitan Area (CMA) of Toronto, while the proportion is roughly 15 and 7 percent for the second generation with one foreign born parent and the third generation respectively. By contrast, the proportion of non-CMA residents increases from first to third generations.

For the Canadian born, the second generation earn more wages than the third generation by about $\$ 3,000$ per year. For the foreign born, the average annual wages decline when their age at migration rises. An extreme example is that the wage differential between an immigrant who migrates before school age and an adult immigrant is as much as $\$ 9,000$ on average. Considering adult immigrants' lead in educational attainment, their low income reflects the fact that their foreign-obtained education is not fully recognized in the host country.

The statistical summary indicates that the second generation and non-adult immigrants are much better educated and earn higher wages than the third generation. For first generation immigrants, age at migration is negatively correlated with their wages. Those who migrate after age 20 perform the worst in the Canadian labour market, despite their highest educational attainment.

\section{$4 \quad$ Model Specification and Results}

A man's wage function can be expressed as:

$$
\ln W=f\left(X, E D U, G E N, E D U^{*} G E N\right)
$$

where $\ln W$ is the logarithm of the person's annual wage; $X$ is a vector of socio-economic variables including age, mother tongue, marital status, visible minority status and CMA of residence. $E D U$ is a vector of five educational attainments, including less than high school (the default), high school diploma, some postsecondary, bachelor's and postgraduate degree. GEN is the vector of the eight abovementioned generation groups. The interaction between EDU and GEN can be used to test for the differential in returns to education across generation groups.

In most research on immigrant earnings, for example Baker and Benjamin (1994) and Aydemir and Sweetman (2006), an immigrant's years-since-migration and implicit 
experience are often included to control for the assimilation effect. However, in this study, I am specifically interested in the wage differentials between the three groups who are mainly brought up in the host country, namely the first generation who migrate at a young age, the second and the third generations. Assimilation of the non-adult immigrants may not be a meaningful question of interest, as their Canadian experience is almost the same as the native-born. For adult first generation immigrants, their generation indicator itself captures both cohort and assimilation effects, because year-since-migration can be obtained through linear transformation of age and age at immigration. Additionally, since implicit experience is usually calculated by subtracting years of schooling and six from an individual's age, it is then omitted when I have already controlled for both age and education.

The OLS regression results using male samples aged 25-54 with positive wages are presented in Table 2. All the education variables have expected signs and magnitude, and are statistically significant. It is noteworthy to mention that the minimum of positive annual wages is greater than 1 dollar and hence its logarithm is always positive. Thus, there is no negative outlier that lowers these coefficient estimates.

In the first column, I do not interact education with generation, but control for age. The second generation with both parents born abroad being the default, the third and first generations earn significantly lower wages. First generation who migrate before school age perform as well as the second generation, which is implied by their insignificant coefficient estimate.

In the second column, I interact education with generation to test for the hypothesis that the return to education varies across generation groups. The coefficient estimates of generation dummies reflects the wage differential among the default education group, that is, high school dropouts. It is not surprising that they show the similar pattern as those in the first column except for that wages of the first generation who migrate during age 5-12 are no longer significantly different from that of the second generation. However, among those with high school diploma and some postsecondary education, the third generation show a small wage premium over the default second generation. Comparing to the default group, the first generation with some postsecondary education are significantly worse off if they migrate at age 5-12, while other first 
generation immigrants do not earn significantly lower. As to university degree holders, the third generation have a wage premium of about 15.6 percent over the default group, while adult first generation immigrants earn less than a second generation by about 12.7 percent. The third generation also lead in wages among those with postgraduate education, and the other generation groups are not significantly different from the default.

The third column controls for all socio-economic characteristics ${ }^{2}$ that are mentioned in equation (1). The coefficient estimates of the third generation become lower in value and less significant. In particular, it turns statistically insignificant among those with a high school diploma. In summary, the cross-generation differences in the returns to education vary over educational level. The third generation earn less than the second generation if they receive high school education and lower. However, the third generation outperform all other generations once they achieve a bachelor's or higher degree. Additionally, regression results indicate that the second generation are not significantly different from immigrants who migrate before age 20 for most educational levels. Adult immigrants with less than high school education or with a bachelor's degree suffer from a wage deficit to the second generation.

My findings improve the research knowledge on the cross-generation difference in the returns to education. It is among the well educated males that the second generation earn less than the first generation. If, according to Caponi (2009), human capital can be divided into manual and intellectual abilities that are respectively associated with low and high educational attainments, the results can be interpreted as a relatively high return to the second generation's manual ability while low return to their intellectual ability. Since labour-intensive jobs are usually less demanding in communication skills or cultural knowledge, immigrants and their children can handle them as well as the third generation and achieve wages parity. On the other hand, if the second generation also inherit their cultural and linguistic traits from their parents, their intellectual ability may not be fully recognized by the Canadian labour market, which results in the wage deficit of those with higher education against the third generation counterparts. In this case, assimilation policy should put more emphasis on first and second generations with university

\footnotetext{
2 The coefficient estimates of the control variables are omitted for the sake of limited space. However, they all have expected signs and magnitudes. For example, a married man earns more than a single one by 28 percent. Compared to Toronto, males living in other cities or areas earn significantly less, except for Oshawa and Windsor.
} 
education to help them better transfer the intellectual ability into productivity.

\section{Explaining the Cross-Generation Differences in Return to Education}

Now that it has been identified that the well educated second and first generations are more likely to suffer from lower returns to education than the third generation, it is then important to explain why their intellectual ability is poorly transferred into wages. As discussed above, since the transferability depends on communication skills and local labour demand, the following analysis then takes into account ethnicity, mother tongue, and area of residence.

\section{$5.1 \quad$ Ethnicity}

I divide the dataset into five sub-samples according to an individual's educational attainment and run the regressions separately for each education sub-sample. On the right hand side, I include a vector of dummies, ETH, indicating nine ethnicity groups, namely Canadian and those from English or French speaking developed countries (the default group, including British, the US, French and Oceanic); European; Jewish; Asian (excluding Mideast); Mideast; Caribbean, Central and South American; African; Aboriginal; and other ethnicities. The wage function for education group $J$ is specified as follows:

$$
\ln W^{J}=f\left(X^{J}, E T H^{J}, G E N^{J}, E T H^{J} * G E N^{J}\right)
$$

where the interaction between ethnicity and generation measures the cross-generation wage differential within a particular ethnic group. Technically, this is equivalent to running one regression by interacting education attainments with all the right-hand-side variables in equation (1). However, a table reporting all the three-dimensional interactions may be messy and inconvenient to interpret. Therefore, I choose regressions with sub-samples and present the results in Table 3 and Table 4 respectively for models with and without the interaction between ethnicity and generation indicators.

In Table 3, ethnicity is not interacted with immigrant generation, and each column stands for a separate regression using the sub-sample from a specific educational level. The coefficients of ethnicity dummies are consistent with the expectation: at all 
educational levels, individuals with Asian, Middle Eastern, Central and South American, African and other ethnic backgrounds earn less than Canadians or those from developed English or French speaking countries. Individuals with European ethnicity experience wage deficit when they have at least a university degree, but the magnitude is moderate. Unlike other ethnicity, Jewish men do not seem to earn lower wages than Canadians except for those with some postsecondary education. The third generation and adult immigrants have lower average wages than the second generation and non-adult immigrants.

I then include interactions of ethnicity and generation and present the estimation results in Table 4. Most of the ethnicity indicators now turn statistically insignificant. The magnitude of some coefficients are not small but their significance level are reduced by the large standard errors. This is probably due to the lack of visible minority observations within the default second generation group.

The first column of Table 4 reports regression results for individuals with less than high school education. Among Canadians and those from developed English/French speaking countries, the second generation outperform the third generation and adult first generation. However, for other ethnic groups, the cross-generation wage differentials are primarily insignificant. Particularly, there is no clear evidence that adult immigrants with less than high school education perform worse than their second generation counterparts within these ethnic groups. This is consistent with the assumption that manual ability can be more easily adapted to the host country.

Estimation results with high school graduate sample are presented in the second column. The third generation do not seem to earn differently from the second generation. Adult immigrants from Asia, Mideast and Central and South America earn significantly less than the second generation, whereas people with European and African background do not show wage differential between generations.

The third column of Table 4 reports regression results for males with some postsecondary education. Of all ethnicity, the third generation at this educational level do not earn higher wages than the second generation. Adult first generation immigrants generally earn less than the second generation, except for those from English or French speaking developed countries or of Jewish ethnicity. 
Estimates for bachelor's degree holders are presented in the fourth column, where the third generation's wages are not higher than those of the second generation for all ethnic groups. Particularly, the third generation with a European background even earn significantly less than their own-ethnic second generation by around 16 percent. Except for the default ethnic group, adult first generation immigrants of all other ethnicity suffer from a wage deficit, ranging from 37 to 76 percent, against the second generation. As to the non-adult first generation immigrants, only those from Central and South America earn significantly less than the second generation, whereas no evidence of wage differential is found for the rest ethnic groups.

As shown in the last column of Table 4, among those with postgraduate degrees, only third generation European earn lower wages than the second generation, whereas there is almost no significant wage differential between the young first generation, the second and the third generations, or within the second generation. The only group that consistently earn lower wages than the default second generation is adult first generation.

It should be noticed again that some of the spurious estimates in Table 4 could be the result of a limited number of observations in that particular education-ethnicitygeneration cell. For example, the count of Jewish males is barely 100 at each educational level, and there is a lack of African first and second generations. The corresponding coefficient estimates should thus be interpreted with caution. Albeit, the estimates of the third generation are either negative or statistically insignificant for all ethnic groups.

To address the problem with small sample size, I aggregate Jewish, Asian, Mideast, African, Central and South American males into one large "non-European" ethnic group and run similar regressions by education. ${ }^{3}$ The estimates of the third generation of this aggregate group are still statistically insignificant in all the regressions, indicating that they do not outperform their own-ethnic second generation. Therefore, the cross-generation differences in the returns to education can be partially explained by ethnicity.

\subsection{Mother Tongue}

Another possible cause for the wage differential to vary across educational levels

\footnotetext{
3 The coefficient estimates are omitted, but they are available upon request.
} 
could be the linguistic differences. Good oral and written communication skills in one or two official languages could add to the productivity of positions that require higher education. It is then reasonable to assume that the wage premium by the third generation who obtain university degree and higher education (Table 2) is also partially due to their superior mastery of official languages relative to the other generations.

To test for this hypothesis, I use the interaction between educational attainment $(J)$ and the dummy that indicates whether a male's mother tongue is an official language $(M)$ to divide my data into ten sub-samples. Regressions including generation dummies and other socio-economic characteristics are specified as follows for each sub-sample:

$$
\ln W^{J, M}=f\left(X^{J, M}, G E N^{J, M}\right)
$$

Again, this specification is the same as regressing the full sample by interacting education attainments and mother tongue with all other right-hand-side variables. For the simplicity of reporting results, I use separate regressions and present the coefficient estimates of generation variables in Table 5.

Among males whose mother tongue is English or French (Panel A), there is almost no wage differential between young first generation, the second generation and the third generation. The third generation with less than high school education earn slightly lower than the similarly educated second generation. However, adult first generation's wage deficit is significant and substantial at every educational level.

Interestingly, the third generation whose mother tongue is not one of the official languages earn substantially less than their second generation counterparts at all educational levels. As shown in Panel B, the third generation's wage deficits range from 13 to 34 percent.

In both panels, the wage differential within the second generation and that between the second generation and young first generation immigrants are mostly insignificant.

The results in Table 5 imply that mother tongue plays an important role in determining the returns to education. Although the causal relationship between language and educational attainment requires further studies, it is safe to conclude that the well-educated third generation's wage premium is partially explained by their excellence in language skills. As shown in Table 1, a large proportion of the second generation (with 
both parents born aboard) and first generation have non-official languages as their mother tongue. Their proficiency in English or French might not be as high as native speakers, and hence hinders the transferring of their intellectual ability and educational achievement into productivity.

\subsection{City of Residence}

Another distinction between the three generations is in their geographic distribution. As suggested by Table 1, more than 80 percent first generation immigrants live in a CMA and a great majority of them choose Toronto, Vancouver or Montreal. About half of the second generation whose parents are both foreign born choose these three cities, whereas the share of those with one foreign born parent is less than one third. As to the third generation, less than one quarter of them reside in the three cities. It is then possible that the clustering of immigrants in Toronto, Vancouver and Montreal intensify the labour market competition within ethnic groups and, in turn, lowers their

equilibrium wages. Such a negative "enclave effect" on earnings has been documented by Warman (2007) using the Census of Canada. If the well educated first and second generation's wage deficit is associated with city of residence, fully controlling for area effects will shrink the wage differential between them and the third generation.

I then repeat the regression model (3) by substituting CMA for mother tongue. In other words, the sub-samples are categorized by the interaction between educational attainments and indicators of Toronto, Vancouver, Montreal, Other CMA and Non-CMA.

Estimates of generation variables are reported by geographic area in Table 6, and each column stands for a separate regression. Generally, the third generation do not earn significantly different from the default second generation group. Among those with some postsecondary education, the third generation in Toronto (Panel A) and other CMA (Panel D) even experience moderate wages deficits. The wage differential within the second generation and that between the second generation and young first generation immigrants are mostly insignificant. These findings indicate that city of residence is also an important determinant of the cross-generation differences in the returns to education. 


\section{Conclusion and Policy Implications}

Among the limited literature on the labour market outcomes of the first, second and third generation immigrants in Canada, Aydemir and Sweetman's (2006) research find that the second generation earn less than the third generation when their advantageous human capital characteristics are controlled for. They attribute the second generation's wage deficit to a relatively low return to their years of schooling. However, no reason for the differences has been provided, which makes the policy implication of their research results quite vague.

To fill the knowledge gap, I use a series of regressions to identify the cross-generation wage differentials of males at various levels of educational attainment, and attempt to explain the causes. This paper complements Aydemir and Sweetman's (2006) study and provide better targeted policy orientation.

My use of a vector of educational attainments instead of a single years-ofschooling variable improves the explanatory power of the models in that it allows the cross-generation differences in the returns to education to vary at different levels of education. As expected, regression results indicate that the third generation's wage premium over other generations is not a constant along the spectrum of education. The third generation with postsecondary or higher education earn more than the similarly educated second generation. However, among males with high school or lower education, the wage differential is statistically insignificant between the third and the second generation. When the labour market assimilation is viewed as a multi-generational process, my findings imply that being born and raised in Canada does not guarantee the second generation to fully achieve it.

The fact that better educated second generation perform worse than the less educated, relative to the third generation may indicate the hardship for immigrants and their children to adapt their intellectual ability into the Canadian labour market. Therefore, policies that support immigrant assimilation should target on those with higher education. This echoes Caponi's (2009) finding that assimilation policy has a larger positive effect on the first and second generation's earnings if it focuses on college educated rather than the high school educated.

Once the targeted population is identified, it is then necessary to explore the 
reasons for the wage differential between the second and third generations with higher education in order to design suitable policies to eliminate the gap.

Compared to the third generation, the second generation is characterized by a high proportion of visible minority, a large share of people whose mother tongue is not an official language and a strong preference over residence in the largest cities. If these characteristics are associated with poor labour market outcome for well educated men, the second generation will then earn less than the third generation. As proof, I run additional regressions on sub-samples defined by the interaction between educational attainment and, consequently, ethnicity, mother tongue and CMA. In almost all sub-samples, the third generation's wage premium disappears, indicating that the cross-generation differences in the return to education is due to the second generation's ethnic and linguistic distance from the mainstream, and to the negative area effect on those living in large CMAs.

The results are consistent with literature that finds strong persistence in immigrant earnings across generations. Borjas (1992 and 1993) and Rooth and Ekberg (2003) argue that the second generation's earnings are substantially influenced by their parents' ethnicity. If immigrants' disadvantage in transferring their human capital into the host-country-specific productivity is passed over to their children through "ethnic capital”, or the quality of ethnic environment as defined by Borjas (1992), the second generation are then expected to earn less than the equally educated third generation.

To increase the recognition of the first and second generations' human capital by the Canadian labour market, policy makers can proceed in two ways. On the one hand, more intensive assimilation policies, such as advanced language training and co-op programmes could be designed to help immigrants with higher education. For example, Chiswick and DebBurman (2004) suggest that English trainings for immigrant parents can facilitate the assimilation of the second generation who are born in non-English speaking families. At the same time, general understanding among immigrants of the Canadian tradition and culture, either in daily life or in workplace, should be encouraged to promote the integration of people from different backgrounds into the mainstream.

On the other hand, the relatively low recognition of the second generation's education could be partially due to employers' preference over some particular ethnic 
groups. As evidence, Oreopoulos (2009) uses a field experiment to show that the interview callback rate for Canadian-born applicants with English names is higher than those with Asian names by as much as 40 percentage points. Considering the increasing proportion of immigrants who are members of visible minority, this may be an even more serious problem for their children's labour market outcome in the future. To eliminate employers' acceptance that is based on ethnicity instead of productivity, policies on employment and pay equity should be reinforced.

Moreover, since the first and second generations tend to cluster in large metropolitan cities, competition among themselves in the local labour markets may be another reason for the second generation's low returns to education. Given this, policies could be designed to encourage immigrants to settle in small cities or non-urban areas. For example, the Provincial Nominee Program may be a means for Atlantic and Prairie Provinces to attract immigrants and their offspring.

Additionally, I explore the difference in labour market outcomes within the second generation males. However, individuals with one foreign born parent do not perform significantly better than those with both parents born abroad, despite the assumption that their difference in family composition may impact on their wages. This partly reflects the fact that the differences in socio-economic characteristics within these second generation groups are not as substantial as those between the second and the third generations.

Given the similarity between the second generation and the first generation who immigrate at young ages, their labour market performance is expected to be similar. My regression results support this hypothesis. For the first generation immigrants who arrive in Canada before 20 years old, particularly those before school age, their wages are not significantly different from the second generation. This finding supports Schaafsma and Sweetman's (2001) conclusion that young immigrants can quickly assimilate in the host country and achieve wage parity with the Canadian born. By contrast, adult first generation immigrants are found to earn significantly less than the second generation, and their wage deficit does not disappear even when ethnicity, mother tongue and CMA are fully controlled.

Although this paper answers the question whether there are cross- generation 
wage differentials at different levels of education and explains the possible causes, the over-time comparison of wages across various generation groups cannot be conducted using one cross-sectional dataset. A combination of two or more censuses or panel data from other surveys may be used for future research on the dynamics of the first, second and third generations' labour market outcome. Once done, a more complete understanding of the multigenerational assimilation and suggestions on immigration policies can be provided. 


\section{Reference}

Aydemir, Abdurrahman, Wen-Hao Chen and Miles Corak (2009) "Intergenerational Earnings Mobility among the Children of Canadian Immigrants," The Review of Economics and Statistics, 91(2), 377-397

Aydemir, Abdurrahman and Mikal Skuterud (2005) "Explaining the Deteriorating Entry Earnings of Canada’s Immigrant Cohorts,” Canadian Journal of Economics, 38(2), 641-671

Aydemir, Abdurrahman and Arthur Sweetman (2006) "First and Second Generation Immigrant Educational Attainment and Labor Market Outcomes: A Comparison of the United States and Canada,” Discussion Paper No. 2298, Institute for the Study of Labor (IZA)

Baker, Michael, and Dwayne Benjamin (1994) "The Performance of Immigrants in the Canadian Labor Market,” Journal of Labor Economics, 12(3), 369-405

Borjas, George J. (1992) “Ethnic Capital and Intergenerational Mobility,” Quarterly Journal of Economics, 107(1), 123-150

Borjas, George J. (1993) “The Intergenerational Mobility of Immigrants,” Journal of Labor Economics, 11(1), 113-135

Caponi, Vincenzo (2009) "Intergenerational Transmission of Abilities and Self Selection of Mexican Immigrants,” Working Paper No. 002, the Department of Economics, Ryerson University

Card, David, John DiNardo and Eugena Estes. 2000. "The More Things Change, Immigrants and the Children of Immigrants in the 1940s, the 1970s, and the 1990s.” In G. Borjas (editor), Issues in the Economics of Immigration, Chicago: NBER and University of Chicago Press, 227-270

Chiswick, Barry R. and Noyna DebBurman (2004) "Educational attainment: analysis by immigrant generation,” Economics of Education Review, Elsevier, 23(4), 361-379

Chiswick, Barry R. and Paul W. Miller (1985) "Immigrant Generation and Income in Australia,” The Economic Record, 61(2), 540-53

Ferrer, Ana and Craig W. Riddell (2008) "Education, credentials, and immigrant earnings,” Canadian Journal of Economics, 41(1), 186-216

Meng, Xin \& Robert G. Gregory (2005) "Intermarriage and the Economic Assimilation of Immigrants,” Journal of Labor Economics, 23(1), 135-176 
Nicoletti, Cheti and John Ermisch (2008) "Intergenerational Earnings Mobility: Changes across Cohorts in Britain,” The B.E. Journal of Economic Analysis \& Policy, 7(2), Contributions to Economic Analysis \& Policy, 1755-1755

Oreopoulos, Philip (2009) "Why Do Skilled Immigrants Struggle in the Labor Market? A Field Experiment with Six Thousand Resumes," NBER Working Papers 15036, National Bureau of Economic Research, Inc.

Rooth, Dan-Olof and Jan Ekberg (2003) "Unemployment and Earnings of second Generation Immigrants in Sweden. Ethnic Background and Parent Composition,” Journal of Population Economics, 16(4), 787-814

Schaafsma, Joseph and Arthur Sweetman (2001) "Immigrant Earnings: Age at Immigration Matters,” Canadian Journal of Economics, 34(4), 1066-1099

Solon, Gary (1992) "Intergenerational Income Mobility in the United States," The American Economic Review, 82(3), 393-408

Van Ours, Jan C. and Justus Veenman (2003) "The Educational Attainment of Second-Generation Immigrants in the Netherlands," Journal of Population Economics. 16(4), 739-753

Warman, Casey (2007) "Ethnic Enclaves and Immigrant Earnings Growth,” Canadian Journal of Economics, 40(2), 401-422 
Table 1

Statistical Summary of Canadian Born and Foreign Born Men, Census 2001

\begin{tabular}{|c|c|c|c|c|c|c|c|c|}
\hline & \multicolumn{4}{|c|}{ (A) Canadian Born: by Generation } & \multicolumn{4}{|c|}{ (B) Foreign born: by Age at Immigration } \\
\hline & $\begin{array}{l}\text { 3rd and } \\
\text { over }\end{array}$ & $\begin{array}{l}\text { 2nd,father } \\
\text { foreign born }\end{array}$ & $\begin{array}{l}\text { 2nd,mother } \\
\text { foreign born }\end{array}$ & $\begin{array}{l}\text { 2nd, Both } \\
\text { foreign born }\end{array}$ & $\begin{array}{c}4 \text { and } \\
\text { less }\end{array}$ & $5-12$ & $13-19$ & $\begin{array}{c}20 \text { and } \\
\text { more }\end{array}$ \\
\hline Average Age & 39.7 & 39.4 & 40.4 & 36.6 & 39.0 & 39.2 & 38.6 & 41.7 \\
\hline Less than High School & 0.22 & 0.16 & 0.16 & 0.13 & 0.12 & 0.18 & 0.24 & 0.19 \\
\hline High School Graduates & 0.31 & 0.29 & 0.30 & 0.27 & 0.28 & 0.28 & 0.27 & 0.22 \\
\hline Some Postsecondary & 0.29 & 0.30 & 0.30 & 0.33 & 0.31 & 0.29 & 0.27 & 0.24 \\
\hline Bachelor's Degree & 0.12 & 0.17 & 0.16 & 0.18 & 0.19 & 0.18 & 0.15 & 0.18 \\
\hline Postgraduate & 0.06 & 0.07 & 0.08 & 0.09 & 0.09 & 0.08 & 0.06 & 0.17 \\
\hline Mother Tongue is Official Language & 0.88 & 0.93 & 0.93 & 0.64 & 0.52 & 0.43 & 0.30 & 0.23 \\
\hline Married & 0.72 & 0.69 & 0.70 & 0.63 & 0.66 & 0.68 & 0.69 & 0.83 \\
\hline Visible Minority & 0.01 & 0.03 & 0.02 & 0.11 & 0.19 & 0.32 & 0.56 & 0.66 \\
\hline Toronto & 0.07 & 0.15 & 0.16 & 0.31 & 0.31 & 0.33 & 0.40 & 0.43 \\
\hline Vancouver & 0.04 & 0.09 & 0.09 & 0.10 & 0.09 & 0.11 & 0.13 & 0.14 \\
\hline Montreal & 0.13 & 0.07 & 0.05 & 0.10 & 0.08 & 0.11 & 0.11 & 0.12 \\
\hline Other CMA & 0.31 & 0.36 & 0.36 & 0.31 & 0.32 & 0.29 & 0.25 & 0.23 \\
\hline Non-CMA & 0.45 & 0.32 & 0.35 & 0.19 & 0.20 & 0.16 & 0.10 & 0.08 \\
\hline Paid Worker & 0.85 & 0.85 & 0.85 & 0.85 & 0.85 & 0.84 & 0.83 & 0.82 \\
\hline Self-Employed & 0.07 & 0.08 & 0.07 & 0.08 & 0.08 & 0.08 & 0.09 & 0.08 \\
\hline Annual Wage & 38,125 & 41,650 & 41,500 & 41,264 & 42,027 & 40,526 & 36,244 & 33,145 \\
\hline Weeks Worked in a Year & 46.7 & 47.4 & 47.3 & 47.6 & 47.3 & 47.6 & 46.4 & 45.1 \\
\hline Hours Worked in a Week & 39.4 & 40.2 & 40.1 & 40.2 & 39.7 & 39.7 & 38.8 & 37.9 \\
\hline Observation & 93,132 & 5,579 & 4,456 & 11,119 & 2,609 & 4,020 & 4,195 & 18,649 \\
\hline
\end{tabular}

NOTE: Sample includes non-aboriginal males aged 25-54 who have positive wages. 
Table 2

Regression Results of Male Wage Function: Immigrant Generation and Educational Attainment

$(1)^{\mathrm{a}} \quad(2)^{\mathrm{a}} \quad(3)^{\mathrm{b}}$

Generation (Default: 2nd Generation, Both Parents Foreign Born)

3rd+ Generation

$-0.077 * * *$

2nd Generation, Father Foreign Born

$(0.010)$

$-0.010$

$(0.016)$

2nd Generation, Mother Foreign Born

$-0.021$

(0.017)

1st Generation, Age at Immigration 0-4

$-0.030$

1st Generation, Age at Immigration 5-12

$(0.021)$

1st Generation, Age at Immigration 13-19

$-0.062 * * *$

(0.018)

$-0.137 * * *$

1st Generation, Age at Immigration > 20

(0.018)

$-0.418 * * *$

Educational Attainment (Default: Less than High School)

$(0.012)$

High School

$0.222 * * *$

$(0.007)$

Postsecondary

$0.386 * * *$

Bachelor's

$(0.007)$

Postgraduate

$0.598 * * *$

$0.689 * * *$

Interactions between High School and:

(0.011)

$\begin{array}{cc}-0.148 * * * & -0.135 * * * \\ (0.027) & (0.026) \\ -0.065 & -0.090 * * \\ (0.041) & (0.041) \\ 0.028 & -0.012 \\ (0.044) & (0.043) \\ -0.033 & 0.003 \\ (0.060) & (0.058) \\ -0.032 & 0.019 \\ (0.044) & (0.044) \\ -0.110^{* * *} & 0.003 \\ (0.040) & (0.040) \\ -0.389 * * * & -0.246 * * * \\ (0.030) & (0.031) \\ & \\ 0.174 * * * & 0.164 * * * \\ (0.031) & (0.030) \\ 0.351 * * * & 0.318 * * * \\ (0.030) & (0.030) \\ 0.517 * * * & 0.511^{* * *} \\ (0.033) & (0.033) \\ 0.611 * * * & 0.590^{* * *} \\ (0.040) & (0.040)\end{array}$

3rd+ Generation

$0.067 * *$

0.052

2nd Generation, Father Foreign Born

$(0.032)$

$(0.032)$

0.051

(0.051)

$-0.034$

$(0.050)$

2nd Generation, Mother Foreign Born

(0.055)

$-0.030$

1st Generation, Age at Immigration 0-4

0.044

(0.053)

(0.072)

0.032

$-0.043$

(0.070)

1st Generation, Age at Immigration 5-12

(0.056)

$-0.029$

$-0.046$

0.055

1st Generation, Age at Immigration 13-19

(0.052)

$-0.038$

0.023

$(0.051)$

1st Generation, Age at Immigration >20 
Table 2 (Continued)

$(1)^{\mathrm{a}} \quad(2)^{\mathrm{a}} \quad(3)^{\mathrm{b}}$

Interactions between Postsecondary and:

3rd+ Generation

\begin{tabular}{|c|c|}
\hline $0.059^{*}$ & $0.056 *$ \\
\hline$(0.032)$ & $(0.031)$ \\
\hline 0.054 & 0.050 \\
\hline (0.050) & $(0.049)$ \\
\hline-0.081 & -0.079 \\
\hline (0.054) & $(0.053)$ \\
\hline-0.037 & -0.029 \\
\hline$(0.071)$ & $(0.069)$ \\
\hline$-0.113 * *$ & -0.071 \\
\hline$(0.055)$ & $(0.054)$ \\
\hline-0.071 & -0.045 \\
\hline$(0.052)$ & $(0.051)$ \\
\hline-0.005 & -0.022 \\
\hline (0.037) & $(0.037)$ \\
\hline $0.156^{* * *}$ & $0.103^{* * *}$ \\
\hline (0.035) & (0.035) \\
\hline 0.090 & 0.039 \\
\hline$(0.056)$ & $(0.055)$ \\
\hline-0.085 & $-0.112^{*}$ \\
\hline$(0.061)$ & $(0.060)$ \\
\hline 0.013 & 0.030 \\
\hline (0.077) & $(0.075)$ \\
\hline 0.086 & $0.132 * *$ \\
\hline (0.061) & $(0.060)$ \\
\hline-0.032 & 0.026 \\
\hline (0.059) & $(0.058)$ \\
\hline$-0.127 * * *$ & $-0.126 * * *$ \\
\hline$(0.041)$ & $(0.040)$ \\
\hline $0.143^{* * *}$ & $0.097 * *$ \\
\hline$(0.043)$ & $(0.042)$ \\
\hline 0.084 & 0.043 \\
\hline$(0.071)$ & $(0.070)$ \\
\hline-0.030 & -0.072 \\
\hline (0.074) & $(0.073)$ \\
\hline 0.010 & 0.025 \\
\hline (0.092) & $(0.090)$ \\
\hline-0.027 & -0.002 \\
\hline$(0.077)$ & $(0.075)$ \\
\hline 0.075 & 0.095 \\
\hline (0.078) & $(0.076)$ \\
\hline-0.051 & -0.067 \\
\hline$(0.047)$ & $(0.046)$ \\
\hline 143,759 & 143,759 \\
\hline 0.08 & 0.12 \\
\hline
\end{tabular}

\begin{tabular}{lccc} 
R-squared & 0.08 & 0.08 & 0.12 \\
\hline NOTES: Standard errors are in parentheses. Significance levels are indicated by $*$ for $10 \%, * *$ for $5 \%$, and
\end{tabular} *** for $1 \%$. The dependent variable is the logarithm of annual wages. The sample is restricted to non-aboriginal males aged 25-54 who have positive wages.

${ }^{\text {a }}$ Regressions control for age only.

${ }^{\mathrm{b}}$ Regressions control for age, mother tongue, marital status, visible minority status and CMA. 
Table 3

Regression Results of Wage Function of Males by Educational Attainments:

No Interaction between Immigrant Generation and Ethnicity

\begin{tabular}{|c|c|c|c|c|c|}
\hline & $\begin{array}{c}\text { Less than } \\
\text { High School }\end{array}$ & $\begin{array}{l}\text { High School } \\
\text { Graduates }\end{array}$ & $\begin{array}{c}\text { Some } \\
\text { Postsecondary }\end{array}$ & $\begin{array}{l}\text { Bachelor's } \\
\text { Degree }\end{array}$ & Postgraduate \\
\hline \multicolumn{6}{|c|}{ Generation (Default: 2nd Generation, Both Parents Foreign Born) } \\
\hline 3rd+ Gen. & $\begin{array}{c}-0.130 * * * \\
(0.032)\end{array}$ & $\begin{array}{c}-0.071^{* * *} \\
(0.020)\end{array}$ & $\begin{array}{c}-0.091^{* * *} \\
(0.018)\end{array}$ & $\begin{array}{c}-0.062 * * \\
(0.025)\end{array}$ & $\begin{array}{c}-0.121^{* * *} \\
(0.037)\end{array}$ \\
\hline \multirow[t]{2}{*}{$\begin{array}{l}\text { 2nd Generation, } \\
\text { Father Foreign Born }\end{array}$} & -0.062 & -0.010 & -0.013 & -0.033 & -0.082 \\
\hline & $(0.048)$ & $(0.030)$ & $(0.028)$ & $(0.037)$ & $(0.058)$ \\
\hline \multirow[t]{2}{*}{$\begin{array}{l}\text { 2nd Generation, } \\
\text { Mother Foreign Born }\end{array}$} & 0.034 & -0.001 & $-0.054^{*}$ & $-0.118^{* * *}$ & $-0.106^{*}$ \\
\hline & $(0.051)$ & $(0.033)$ & $(0.030)$ & $(0.041)$ & $(0.060)$ \\
\hline \multirow[t]{2}{*}{$\begin{array}{l}\text { 1st Generation, } \\
\text { Age at Immigration 0-4 }\end{array}$} & -0.025 & 0.024 & -0.054 & -0.012 & -0.026 \\
\hline & $(0.067)$ & $(0.040)$ & $(0.035)$ & $(0.046)$ & $(0.068)$ \\
\hline \multirow[t]{2}{*}{$\begin{array}{l}\text { 1st Generation, } \\
\text { Age at Immigration 5-12 }\end{array}$} & 0.005 & -0.030 & $-0.108^{* * *}$ & $0.083^{* *}$ & -0.064 \\
\hline & $(0.050)$ & $(0.034)$ & $(0.031)$ & $(0.040)$ & $(0.061)$ \\
\hline \multirow{2}{*}{$\begin{array}{l}\text { 1st Generation, } \\
\text { Age at Immigration 13-19 }\end{array}$} & -0.003 & $-0.063 *$ & $-0.102 * * *$ & -0.049 & 0.030 \\
\hline & $(0.047)$ & $(0.034)$ & $(0.032)$ & $(0.042)$ & $(0.065)$ \\
\hline \multirow[t]{2}{*}{$\begin{array}{l}\text { 1st Generation, } \\
\text { Age at Immigration >20 }\end{array}$} & $-0.206 * * *$ & $-0.216^{* * *}$ & $-0.283 * * *$ & $-0.441 * * *$ & $-0.391 * * *$ \\
\hline & $(0.038)$ & $(0.026)$ & $(0.023)$ & $(0.029)$ & $(0.038)$ \\
\hline \multicolumn{6}{|c|}{ Ethnicity (Default: Canadian, U.S., U.K. and Australia) } \\
\hline European & $\begin{array}{c}0.022 \\
(0.023)\end{array}$ & $\begin{array}{l}0.036^{* *} \\
(0.017)\end{array}$ & $\begin{array}{c}0.009 \\
(0.016)\end{array}$ & $\begin{array}{l}-0.046^{*} \\
(0.024)\end{array}$ & $\begin{array}{c}-0.097 * * * \\
(0.033)\end{array}$ \\
\hline Jewish & $\begin{array}{c}0.155 \\
(0.165)\end{array}$ & $\begin{array}{c}0.031 \\
(0.094)\end{array}$ & $\begin{array}{l}-0.232^{* * *} \\
(0.075)\end{array}$ & $\begin{array}{c}0.091 \\
(0.062)\end{array}$ & $\begin{array}{l}-0.009 \\
(0.064)\end{array}$ \\
\hline Asian & $\begin{array}{c}-0.271^{* * *} \\
(0.035)\end{array}$ & $\begin{array}{c}-0.219 * * * \\
(0.026)\end{array}$ & $\begin{array}{c}-0.149 * * * \\
(0.024)\end{array}$ & $\begin{array}{c}-0.223 * * * \\
(0.027)\end{array}$ & $\begin{array}{c}-0.265 * * * \\
(0.035)\end{array}$ \\
\hline Mideast & $\begin{array}{c}-0.435^{* * * *} \\
(0.070)\end{array}$ & $\begin{array}{c}-0.361 * * * \\
(0.053)\end{array}$ & $\begin{array}{c}-0.391^{* * *} \\
(0.047)\end{array}$ & $\begin{array}{c}-0.270^{* * *} \\
(0.047)\end{array}$ & $\begin{array}{c}-0.337 * * * \\
(0.057)\end{array}$ \\
\hline Central and South American & $\begin{array}{l}-0.152 * * * \\
(0.058)\end{array}$ & $\begin{array}{c}-0.106 * * * \\
(0.040)\end{array}$ & $\begin{array}{c}-0.127 * * * \\
(0.036)\end{array}$ & $\begin{array}{c}-0.139 * * * \\
(0.053)\end{array}$ & $\begin{array}{l}-0.248 * * * \\
(0.081)\end{array}$ \\
\hline African & $\begin{array}{c}-0.229 * * \\
(0.105)\end{array}$ & $\begin{array}{c}-0.501 * * * \\
(0.069)\end{array}$ & $\begin{array}{c}-0.482 * * * \\
(0.062)\end{array}$ & $\begin{array}{c}-0.538 * * * \\
(0.080)\end{array}$ & $\begin{array}{c}-0.581 * * * \\
(0.090)\end{array}$ \\
\hline Other Ethnicity & $\begin{array}{c}-0.212 * * * \\
(0.019)\end{array}$ & $\begin{array}{c}-0.172 * * * \\
(0.015)\end{array}$ & $\begin{array}{c}-0.176^{* * *} \\
(0.014)\end{array}$ & $\begin{array}{c}-0.131^{* * *} \\
(0.020)\end{array}$ & $\begin{array}{c}-0.145^{* * *} \\
(0.030)\end{array}$ \\
\hline Observations & 28,951 & 41,889 & 41,644 & 20,419 & 10,856 \\
\hline R-squared & 0.03 & 0.04 & 0.05 & 0.12 & 0.11 \\
\hline
\end{tabular}

NOTES: Same as Table $2\left(^{a}\right)$ except that visible minority status is not included in the regressions. 
Table 4

Regression Results of Wage Function of Males by Educational Attainments: Interaction between Immigrant Generation and Ethnicity

\begin{tabular}{|c|c|c|c|c|c|}
\hline & $\begin{array}{l}\text { Less than } \\
\text { High School }\end{array}$ & $\begin{array}{l}\text { High School } \\
\text { Graduates }\end{array}$ & $\begin{array}{c}\text { Some } \\
\text { Postsecondary }\end{array}$ & $\begin{array}{l}\text { Bachelor's } \\
\text { Degree }\end{array}$ & Postgraduate \\
\hline \multicolumn{6}{|c|}{ Generation (Default: 2nd Generation, Both Parents Foreign Born) } \\
\hline 3rd+ Gen. & $\begin{array}{c}-0.115^{* *} \\
(0.053)\end{array}$ & $\begin{array}{l}-0.014 \\
(0.033)\end{array}$ & $\begin{array}{c}0.015 \\
(0.030)\end{array}$ & $\begin{array}{c}0.067 \\
(0.043)\end{array}$ & $\begin{array}{c}0.033 \\
(0.061)\end{array}$ \\
\hline 2nd Gen. Father Foreign Born & $\begin{array}{l}-0.081 \\
(0.067)\end{array}$ & $\begin{array}{c}0.006 \\
(0.043)\end{array}$ & $\begin{array}{c}0.063 \\
(0.039)\end{array}$ & $\begin{array}{c}0.076 \\
(0.053)\end{array}$ & $\begin{array}{c}0.016 \\
(0.080)\end{array}$ \\
\hline 2nd Gen. Mother Foreign Born & $\begin{array}{l}-0.034 \\
(0.069)\end{array}$ & $\begin{array}{c}0.031 \\
(0.044)\end{array}$ & $\begin{array}{c}0.008 \\
(0.040)\end{array}$ & $\begin{array}{l}-0.029 \\
(0.056)\end{array}$ & $\begin{array}{l}-0.002 \\
(0.080)\end{array}$ \\
\hline 1st Gen. Age at Immigration 0-4 & $\begin{array}{c}0.038 \\
(0.119)\end{array}$ & $\begin{array}{l}-0.029 \\
(0.066)\end{array}$ & $\begin{array}{l}-0.020 \\
(0.060)\end{array}$ & $\begin{array}{c}0.035 \\
(0.081)\end{array}$ & $\begin{array}{c}0.025 \\
(0.122)\end{array}$ \\
\hline 1st Gen. Age at Immigration 5-12 & $\begin{array}{l}-0.050 \\
(0.097)\end{array}$ & $\begin{array}{l}-0.047 \\
(0.061)\end{array}$ & $\begin{array}{l}-0.035 \\
(0.056)\end{array}$ & $\begin{array}{c}0.110 \\
(0.078)\end{array}$ & $\begin{array}{l}-0.037 \\
(0.112)\end{array}$ \\
\hline 1st Gen. Age at Immigration 13-19 & $\begin{array}{l}-0.008 \\
(0.122)\end{array}$ & $\begin{array}{l}-0.088 \\
(0.074)\end{array}$ & $\begin{array}{c}-0.157^{* *} \\
(0.068)\end{array}$ & $\begin{array}{l}-0.025 \\
(0.097)\end{array}$ & $\begin{array}{c}0.089 \\
(0.143)\end{array}$ \\
\hline 1st Gen. Age at Immigration > 20 & $\begin{array}{c}-0.255^{* * *} \\
(0.084)\end{array}$ & $\begin{array}{c}-0.150^{* * *} \\
(0.053)\end{array}$ & $\begin{array}{l}-0.050 \\
(0.043)\end{array}$ & $\begin{array}{l}-0.039 \\
(0.064)\end{array}$ & $\begin{array}{l}-0.011 \\
(0.075)\end{array}$ \\
\hline \multicolumn{6}{|c|}{ Ethnicity (Default: Canadian, U.S., U.K. and Australia) } \\
\hline European & $\begin{array}{l}-0.020 \\
(0.066)\end{array}$ & $\begin{array}{c}0.049 \\
(0.041)\end{array}$ & $\begin{array}{c}0.111^{* * *} \\
(0.037)\end{array}$ & $\begin{array}{c}0.129 * * \\
(0.052)\end{array}$ & $\begin{array}{c}0.178^{* *} \\
(0.076)\end{array}$ \\
\hline Jewish & $\begin{array}{c}0.675 \\
(0.540)\end{array}$ & $\begin{array}{l}-0.026 \\
(0.288)\end{array}$ & $\begin{array}{c}-0.410^{* *} \\
(0.192)\end{array}$ & $\begin{array}{c}0.169 \\
(0.153)\end{array}$ & $\begin{array}{c}0.211 \\
(0.188)\end{array}$ \\
\hline Asian & $\begin{array}{c}0.116 \\
(0.168)\end{array}$ & $\begin{array}{l}-0.066 \\
(0.086)\end{array}$ & $\begin{array}{c}0.003 \\
(0.072)\end{array}$ & $\begin{array}{l}-0.017 \\
(0.069)\end{array}$ & $\begin{array}{c}0.047 \\
(0.105)\end{array}$ \\
\hline Mideast & $\begin{array}{c}0.120 \\
(0.344)\end{array}$ & $\begin{array}{c}0.246 \\
(0.197)\end{array}$ & $\begin{array}{c}0.114 \\
(0.192)\end{array}$ & $\begin{array}{l}-0.054 \\
(0.193)\end{array}$ & $\begin{array}{l}-0.020 \\
(0.275)\end{array}$ \\
\hline Central and South American & $\begin{array}{l}-0.179 \\
(0.180)\end{array}$ & $\begin{array}{c}0.240 * * \\
(0.107)\end{array}$ & $\begin{array}{l}0.163^{*} \\
(0.085)\end{array}$ & $\begin{array}{c}0.291 * * \\
(0.116)\end{array}$ & $\begin{array}{l}-0.185 \\
(0.207)\end{array}$ \\
\hline African & $\begin{array}{c}0.697 \\
(0.762)\end{array}$ & $\begin{array}{l}-0.205 \\
(0.255)\end{array}$ & $\begin{array}{c}0.389 \\
(0.515)\end{array}$ & $\begin{array}{l}-0.199 \\
(0.296)\end{array}$ & $\begin{array}{c}0.292 \\
(0.538)\end{array}$ \\
\hline Other Ethnicity & $\begin{array}{l}-0.052 \\
(0.105)\end{array}$ & $\begin{array}{l}-0.087 \\
(0.063)\end{array}$ & $\begin{array}{c}0.030 \\
(0.054)\end{array}$ & $\begin{array}{c}0.030 \\
(0.068)\end{array}$ & $\begin{array}{c}0.053 \\
(0.109)\end{array}$ \\
\hline \multicolumn{6}{|c|}{ Interactions between European ethnicity and: } \\
\hline 3rd+ Gen. & $\begin{array}{c}0.086 \\
(0.074)\end{array}$ & $\begin{array}{c}0.034 \\
(0.048)\end{array}$ & $\begin{array}{l}-0.059 \\
(0.045)\end{array}$ & $\begin{array}{c}-0.164 * * \\
(0.066)\end{array}$ & $\begin{array}{c}-0.201^{* *} \\
(0.102)\end{array}$ \\
\hline 2nd Gen. Father Foreign Born & $\begin{array}{l}-0.034 \\
(0.116)\end{array}$ & $\begin{array}{c}0.040 \\
(0.078)\end{array}$ & $\begin{array}{l}-0.123^{*} \\
(0.075)\end{array}$ & $\begin{array}{c}-0.230^{* *} \\
(0.100)\end{array}$ & $\begin{array}{l}-0.243 \\
(0.180)\end{array}$ \\
\hline 2nd Gen. Mother Foreign Born & $\begin{array}{c}0.108 \\
(0.142)\end{array}$ & $\begin{array}{l}-0.066 \\
(0.099)\end{array}$ & $\begin{array}{c}-0.220^{* *} \\
(0.096)\end{array}$ & $\begin{array}{c}-0.370^{* *} \\
(0.147)\end{array}$ & $\begin{array}{l}-0.203 \\
(0.194)\end{array}$ \\
\hline 1st Gen. Age at Immigration 0-4 & $\begin{array}{c}0.019 \\
(0.150)\end{array}$ & $\begin{array}{c}0.084 \\
(0.089)\end{array}$ & $\begin{array}{c}0.009 \\
(0.081)\end{array}$ & $\begin{array}{l}-0.041 \\
(0.116)\end{array}$ & $\begin{array}{l}-0.107 \\
(0.171)\end{array}$ \\
\hline 1st Gen. Age at Immigration 5-12 & $\begin{array}{c}0.138 \\
(0.120)\end{array}$ & $\begin{array}{c}0.070 \\
(0.082)\end{array}$ & $\begin{array}{l}-0.028 \\
(0.076)\end{array}$ & $\begin{array}{l}-0.045 \\
(0.110)\end{array}$ & $\begin{array}{l}-0.048 \\
(0.157)\end{array}$ \\
\hline 1st Gen. Age at Immigration 13-19 & $\begin{array}{c}0.046 \\
(0.140)\end{array}$ & $\begin{array}{c}0.011 \\
(0.095)\end{array}$ & $\begin{array}{c}0.197^{* *} \\
(0.092)\end{array}$ & $\begin{array}{c}0.126 \\
(0.145)\end{array}$ & $\begin{array}{l}-0.323 \\
(0.200)\end{array}$ \\
\hline 1st Gen. Age at Immigration $>20$ & $\begin{array}{c}0.146 \\
(0.100)\end{array}$ & $\begin{array}{l}-0.040 \\
(0.070)\end{array}$ & $\begin{array}{c}-0.235^{* * *} \\
(0.058)\end{array}$ & $\begin{array}{c}-0.372 * * * \\
(0.089)\end{array}$ & $\begin{array}{c}-0.489 * * * \\
(0.097)\end{array}$ \\
\hline
\end{tabular}


Table 4 (Continued)

\begin{tabular}{ccccc} 
Less than & High School & Some & Bachelor's & Postgraduate \\
High School & Graduates & Postsecondary & Degree & \\
\hline
\end{tabular}

Interactions between Jewish ethnicity and:

\begin{tabular}{|c|c|c|c|c|c|}
\hline 3rd+ Gen. & $\begin{array}{c}-0.295 \\
(0.612)\end{array}$ & $\begin{array}{c}0.213 \\
(0.330)\end{array}$ & $\begin{array}{c}0.363 \\
(0.232)\end{array}$ & $\begin{array}{l}-0.141 \\
(0.177)\end{array}$ & $\begin{array}{l}-0.266 \\
(0.213)\end{array}$ \\
\hline 2nd Gen. Father Foreign Born & - & $\begin{array}{l}-0.414 \\
(0.369)\end{array}$ & $\begin{array}{c}0.096 \\
(0.354)\end{array}$ & $\begin{array}{c}0.072 \\
(0.308)\end{array}$ & $\begin{array}{c}0.260 \\
(0.309)\end{array}$ \\
\hline 2nd Gen. Mother Foreign Born & $\begin{array}{l}-0.059 \\
(1.204)\end{array}$ & $\begin{array}{l}-0.176 \\
(0.460)\end{array}$ & $\begin{array}{l}-0.329 \\
(0.442)\end{array}$ & $\begin{array}{l}-0.115 \\
(0.290)\end{array}$ & $\begin{array}{l}-0.518 \\
(0.382)\end{array}$ \\
\hline 1st Gen. Age at Immigration 0-4 & $\begin{array}{c}-0.382 \\
(0.939)\end{array}$ & $\begin{array}{c}-1.320 * * \\
(0.621)\end{array}$ & $\begin{array}{c}0.231 \\
(0.659)\end{array}$ & $\begin{array}{c}0.047 \\
(0.398)\end{array}$ & $\begin{array}{c}-0.920^{* *} \\
(0.469)\end{array}$ \\
\hline 1st Gen. Age at Immigration 5-12 & $\begin{array}{c}-0.596 \\
(0.727)\end{array}$ & $\begin{array}{c}0.110 \\
(0.485)\end{array}$ & $\begin{array}{l}-0.041 \\
(0.486)\end{array}$ & $\begin{array}{l}-0.430 \\
(0.313)\end{array}$ & $\begin{array}{c}0.116 \\
(0.433)\end{array}$ \\
\hline 1st Gen. Age at Immigration 13-19 & $\begin{array}{l}-0.470 \\
(0.704)\end{array}$ & $\begin{array}{c}0.308 \\
(0.465)\end{array}$ & $\begin{array}{c}0.514 \\
(0.445)\end{array}$ & $\begin{array}{c}0.056 \\
(0.376)\end{array}$ & $\begin{array}{l}-0.261 \\
(0.473)\end{array}$ \\
\hline 1st Gen. Age at Immigration $>20$ & $\begin{array}{c}-0.614 \\
(0.626) \\
\end{array}$ & $\begin{array}{c}0.345 \\
(0.354) \\
\end{array}$ & $\begin{array}{c}0.000 \\
(0.229) \\
\end{array}$ & $\begin{array}{c}-0.470 * * \\
(0.212) \\
\end{array}$ & $\begin{array}{c}-0.453^{* *} \\
(0.222) \\
\end{array}$ \\
\hline \multicolumn{6}{|l|}{ Interactions between Asian ethnicity and: } \\
\hline 3rd+ Gen. & $\begin{array}{c}0.053 \\
(0.247)\end{array}$ & $\begin{array}{l}-0.155 \\
(0.157)\end{array}$ & $\begin{array}{c}0.175 \\
(0.131)\end{array}$ & $\begin{array}{c}0.010 \\
(0.140)\end{array}$ & $\begin{array}{c}0.018 \\
(0.243)\end{array}$ \\
\hline 2nd Gen. Father Foreign Born & $\begin{array}{c}0.130 \\
(0.780)\end{array}$ & $\begin{array}{l}-0.478 \\
(0.347)\end{array}$ & $\begin{array}{c}0.134 \\
(0.345)\end{array}$ & $\begin{array}{c}0.436 \\
(0.303)\end{array}$ & $\begin{array}{l}-0.267 \\
(0.431)\end{array}$ \\
\hline 2nd Gen. Mother Foreign Born & $\begin{array}{l}-0.201 \\
(0.566)\end{array}$ & $\begin{array}{c}0.099 \\
(0.247)\end{array}$ & $\begin{array}{c}0.291 \\
(0.279)\end{array}$ & $\begin{array}{c}0.296 \\
(0.228)\end{array}$ & $\begin{array}{l}-0.696 \\
(0.666)\end{array}$ \\
\hline 1st Gen. Age at Immigration 0-4 & $\begin{array}{l}-0.428 \\
(0.349)\end{array}$ & $\begin{array}{c}0.085 \\
(0.161)\end{array}$ & $\begin{array}{c}0.071 \\
(0.137)\end{array}$ & $\begin{array}{c}0.117 \\
(0.133)\end{array}$ & $\begin{array}{c}0.169 \\
(0.209)\end{array}$ \\
\hline 1st Gen. Age at Immigration 5-12 & $\begin{array}{l}-0.360 \\
(0.222)\end{array}$ & $\begin{array}{l}-0.035 \\
(0.123)\end{array}$ & $\begin{array}{l}-0.097 \\
(0.108)\end{array}$ & $\begin{array}{c}0.092 \\
(0.112)\end{array}$ & $\begin{array}{c}0.203 \\
(0.181)\end{array}$ \\
\hline 1st Gen. Age at Immigration 13-19 & $\begin{array}{l}-0.321 \\
(0.208)\end{array}$ & $\begin{array}{l}-0.101 \\
(0.120)\end{array}$ & $\begin{array}{c}0.030 \\
(0.105)\end{array}$ & $\begin{array}{l}-0.032 \\
(0.123)\end{array}$ & $\begin{array}{c}0.085 \\
(0.193)\end{array}$ \\
\hline 1st Gen. Age at Immigration $>20$ & $\begin{array}{c}-0.373 * * \\
(0.181)\end{array}$ & $\begin{array}{c}-0.239 * * \\
(0.098)\end{array}$ & $\begin{array}{c}-0.324^{* * *} \\
(0.081)\end{array}$ & $\begin{array}{c}-0.545^{* * *} \\
(0.087)\end{array}$ & $\begin{array}{c}-0.548^{* * * *} \\
(0.118)\end{array}$ \\
\hline \multicolumn{6}{|c|}{ Interactions between Mideast ethnicity and: } \\
\hline 3rd+ Gen. & $\begin{array}{c}-0.263 \\
(0.455)\end{array}$ & $\begin{array}{c}0.023 \\
(0.372)\end{array}$ & $\begin{array}{l}-0.448 \\
(0.312)\end{array}$ & $\begin{array}{c}0.019 \\
(0.328)\end{array}$ & $\begin{array}{l}-0.008 \\
(0.601)\end{array}$ \\
\hline 2nd Gen. Father Foreign Born & $\begin{array}{c}0.163 \\
(1.131)\end{array}$ & $\begin{array}{l}-0.145 \\
(0.582)\end{array}$ & $\begin{array}{c}0.385 \\
(0.548)\end{array}$ & - & $\begin{array}{c}0.573 \\
(0.968)\end{array}$ \\
\hline 2nd Gen. Mother Foreign Born & - & $\begin{array}{l}-0.749 \\
(0.970)\end{array}$ & $\begin{array}{c}0.068 \\
(0.910)\end{array}$ & $\begin{array}{c}0.469 \\
(0.654)\end{array}$ & $\begin{array}{c}0.021 \\
(0.973)\end{array}$ \\
\hline 1st Gen. Age at Immigration 0-4 & $\begin{array}{c}-0.345 \\
(0.718)\end{array}$ & $\begin{array}{c}0.006 \\
(0.584)\end{array}$ & $\begin{array}{l}-0.168 \\
(0.344)\end{array}$ & $\begin{array}{l}-0.025 \\
(0.358)\end{array}$ & $\begin{array}{c}0.571 \\
(0.548)\end{array}$ \\
\hline 1st Gen. Age at Immigration 5-12 & $\begin{array}{l}-0.632 \\
(0.480)\end{array}$ & $\begin{array}{l}-0.481 \\
(0.332)\end{array}$ & $\begin{array}{l}-0.389 \\
(0.292)\end{array}$ & $\begin{array}{l}-0.036 \\
(0.271)\end{array}$ & $\begin{array}{l}-0.102 \\
(0.438)\end{array}$ \\
\hline 1st Gen. Age at Immigration 13-19 & $\begin{array}{l}-0.469 \\
(0.409)\end{array}$ & $\begin{array}{l}-0.260 \\
(0.244)\end{array}$ & $\begin{array}{l}-0.068 \\
(0.239)\end{array}$ & $\begin{array}{c}0.125 \\
(0.244)\end{array}$ & $\begin{array}{c}0.128 \\
(0.374)\end{array}$ \\
\hline 1st Gen. Age at Immigration $>20$ & $\begin{array}{r}-0.460 \\
(0.358) \\
\end{array}$ & $\begin{array}{c}-0.691 * * * \\
(0.209) \\
\end{array}$ & $\begin{array}{c}-0.640 * * * \\
(0.201) \\
\end{array}$ & $\begin{array}{c}-0.473 * * \\
(0.204) \\
\end{array}$ & $\begin{array}{c}-0.468^{*} \\
(0.283) \\
\end{array}$ \\
\hline
\end{tabular}


Table 4 (Continued)

\begin{tabular}{ccccc} 
Less than & $\begin{array}{c}\text { High School } \\
\text { High School }\end{array}$ & $\begin{array}{c}\text { Some } \\
\text { Graduates }\end{array}$ & $\begin{array}{c}\text { Bachelor's } \\
\text { Postsecondary }\end{array}$ & Postgraduate \\
\hline
\end{tabular}

Interactions between Central and South American ethnicity and:

\begin{tabular}{|c|c|c|c|c|c|}
\hline 3rd+ Gen. & $\begin{array}{l}-0.067 \\
(0.291)\end{array}$ & $\begin{array}{l}-0.347 \\
(0.229)\end{array}$ & $\begin{array}{c}0.010 \\
(0.226)\end{array}$ & $\begin{array}{c}-0.126 \\
(0.332)\end{array}$ & $\begin{array}{c}0.607 \\
(0.687)\end{array}$ \\
\hline 2nd Gen. Father Foreign Born & 0.391 & -0.355 & -0.051 & 0.046 & 0.810 \\
\hline & (1.093) & $(0.375)$ & $(0.283)$ & $(0.456)$ & $(0.949)$ \\
\hline 2nd Gen. Mother Foreign Born & 0.482 & -0.599 & -0.415 & 0.456 & 0.422 \\
\hline & $(0.648)$ & $(0.487)$ & $(0.453)$ & $(0.456)$ & $(0.952)$ \\
\hline 1st Gen. Age at Immigration 0-4 & -0.658 & -0.064 & -0.136 & $-0.405^{*}$ & 0.395 \\
\hline & $(0.577)$ & $(0.232)$ & $(0.188)$ & $(0.225)$ & $(0.445)$ \\
\hline 1st Gen. Age at Immigration 5-12 & 0.076 & $-0.381^{* *}$ & $-0.392 * * *$ & $-0.503 * *$ & -0.248 \\
\hline & $(0.286)$ & $(0.163)$ & $(0.141)$ & $(0.227)$ & $(0.473)$ \\
\hline 1st Gen. Age at Immigration 13-19 & -0.283 & $-0.336 * *$ & -0.171 & $-0.529 * *$ & 0.219 \\
\hline & $(0.253)$ & $(0.165)$ & $(0.137)$ & $(0.237)$ & $(0.523)$ \\
\hline 1st Gen. Age at Immigration $>20$ & 0.149 & $-0.472 * * *$ & $-0.504 * * *$ & $-0.757 * * *$ & -0.237 \\
\hline & $(0.202)$ & $(0.124)$ & $(0.102)$ & $(0.141)$ & $(0.229)$ \\
\hline Interactions between African ethnici & & & & & \\
\hline 3rd+ Gen. & -0.418 & -0.051 & -0.392 & 0.124 & -0.100 \\
\hline & $(0.879)$ & $(0.354)$ & $(0.630)$ & $(0.689)$ & $(0.759)$ \\
\hline 2nd Gen. Father Foreign Born & - & -0.146 & - & - & - \\
\hline & - & $(0.989)$ & - & - & - \\
\hline 2nd Gen. Mother Foreign Born & - & 1.220 & - & - & - \\
\hline & - & $(0.983)$ & - & - & - \\
\hline 1st Gen. Age at Immigration 0-4 & -1.124 & -0.333 & -0.926 & -0.946 & - \\
\hline & $(1.084)$ & $(0.608)$ & $(0.652)$ & $(0.593)$ & - \\
\hline 1st Gen. Age at Immigration 5-12 & -0.579 & 0.199 & -0.369 & -0.134 & -0.785 \\
\hline & $(0.846)$ & $(0.397)$ & $(0.605)$ & $(0.470)$ & $(0.765)$ \\
\hline 1st Gen. Age at Immigration 13-19 & -1.120 & -0.086 & $-0.957^{*}$ & 0.055 & -0.568 \\
\hline & $(0.859)$ & $(0.342)$ & $(0.561)$ & $(0.438)$ & $(0.723)$ \\
\hline 1st Gen. Age at Immigration $>20$ & -0.929 & -0.412 & $-1.000^{*}$ & $-0.613^{* *}$ & $-1.099 * *$ \\
\hline & $(0.773)$ & $(0.270)$ & $(0.519)$ & $(0.312)$ & $(0.548)$ \\
\hline Interactions between other ethnicity & & & & & \\
\hline 3rd+ Gen. & -0.037 & 0.015 & -0.089 & 0.021 & -0.073 \\
\hline & $(0.109)$ & $(0.066)$ & $(0.057)$ & $(0.073)$ & $(0.116)$ \\
\hline 2nd Gen. Father Foreign Born & -0.028 & 0.012 & -0.106 & -0.068 & 0.009 \\
\hline & $(0.160)$ & $(0.098)$ & $(0.086)$ & $(0.112)$ & $(0.182)$ \\
\hline 2nd Gen. Mother Foreign Born & 0.171 & -0.096 & 0.015 & 0.172 & 0.228 \\
\hline & $(0.181)$ & $(0.111)$ & $(0.093)$ & $(0.126)$ & $(0.195)$ \\
\hline 1st Gen. Age at Immigration 0-4 & -0.327 & 0.171 & -0.096 & -0.040 & -0.059 \\
\hline & $(0.266)$ & $(0.138)$ & $(0.121)$ & $(0.148)$ & $(0.212)$ \\
\hline 1st Gen. Age at Immigration 5-12 & 0.234 & -0.031 & -0.029 & -0.064 & -0.114 \\
\hline & $(0.197)$ & $(0.116)$ & $(0.102)$ & $(0.131)$ & $(0.196)$ \\
\hline 1st Gen. Age at Immigration 13-19 & 0.039 & 0.023 & -0.055 & -0.121 & -0.190 \\
\hline & $(0.188)$ & $(0.121)$ & $(0.106)$ & $(0.147)$ & $(0.215)$ \\
\hline 1st Gen. Age at Immigration $>20$ & -0.078 & -0.077 & $-0.444^{* * *}$ & $-0.457 * * *$ & $-0.348 * * *$ \\
\hline & $(0.135)$ & $(0.088)$ & $(0.073)$ & $(0.095)$ & $(0.127)$ \\
\hline Observations & 28,951 & 41,889 & 41,644 & 20,419 & 10,856 \\
\hline R-squared & 0.06 & 0.08 & 0.09 & 0.16 & 0.14 \\
\hline
\end{tabular}


NOTES: Every column stands for a separate regression. Standard errors are in parentheses. Significance levels are indicated by * for $10 \%, * *$ for $5 \%$, and $* * *$ for $1 \%$. The dependent variable is the logarithm of annual wages. Regressions control for age, mother tongue, marital status and CMA. The sample is restricted to non-aboriginal males aged 25-54 who have positive wages. 
Table 5

\section{Regression Results of Wage Function of Males by Education and Mother Tongue: Immigrant Generation}

\begin{tabular}{|c|c|c|c|c|c|}
\hline & \multicolumn{5}{|c|}{ (A) Mother Tongue is Official Language(s) } \\
\hline & $\begin{array}{l}\text { Less than } \\
\text { High School }\end{array}$ & $\begin{array}{l}\text { High School } \\
\text { Graduates }\end{array}$ & $\begin{array}{c}\text { Some } \\
\text { Postsecondary }\end{array}$ & $\begin{array}{l}\text { Bachelor's } \\
\text { Degree }\end{array}$ & Postgraduate \\
\hline 3rd+ Gen. & $\begin{array}{c}-0.070^{*} \\
(0.036)\end{array}$ & $\begin{array}{c}-0.014 \\
(0.022)\end{array}$ & $\begin{array}{l}-0.025 \\
(0.019)\end{array}$ & $\begin{array}{c}0.016 \\
0.027)\end{array}$ & $\begin{array}{l}-0.045 \\
0.039)\end{array}$ \\
\hline 2nd Gen. Father Foreign Born & $\begin{array}{l}-0.058 \\
(0.050)\end{array}$ & $\begin{array}{c}0.002 \\
(0.032)\end{array}$ & $\begin{array}{c}0.010 \\
(0.029)\end{array}$ & $\begin{array}{c}0.025 \\
(0.037)\end{array}$ & $\begin{array}{l}-0.028 \\
(0.058)\end{array}$ \\
\hline 2nd Gen. Mother Foreign Born & $\begin{array}{c}0.015 \\
(0.054)\end{array}$ & $\begin{array}{c}0.025 \\
(0.034)\end{array}$ & $\begin{array}{l}-0.035 \\
(0.031)\end{array}$ & $\begin{array}{l}-0.060 \\
(0.041)\end{array}$ & $\begin{array}{l}-0.076 \\
(0.059)\end{array}$ \\
\hline 1st Gen. Age at Immigration 0-4 & $\begin{array}{c}0.126 \\
(0.092)\end{array}$ & $\begin{array}{c}0.014 \\
(0.052)\end{array}$ & $\begin{array}{l}-0.059 \\
(0.046)\end{array}$ & $\begin{array}{l}-0.006 \\
(0.057)\end{array}$ & $\begin{array}{l}-0.027 \\
(0.087)\end{array}$ \\
\hline 1st Gen. Age at Immigration 5-12 & $\begin{array}{c}0.033 \\
(0.077)\end{array}$ & $\begin{array}{l}-0.020 \\
(0.047)\end{array}$ & $\begin{array}{l}-0.050 \\
(0.042)\end{array}$ & $\begin{array}{l}0.109 * * \\
(0.055)\end{array}$ & $\begin{array}{l}-0.103 \\
(0.080)\end{array}$ \\
\hline 1st Gen. Age at Immigration 13-19 & $\begin{array}{l}-0.042 \\
(0.089)\end{array}$ & $\begin{array}{c}0.020 \\
(0.054)\end{array}$ & $\begin{array}{l}-0.080 * \\
(0.048)\end{array}$ & $\begin{array}{l}-0.050 \\
(0.065)\end{array}$ & $\begin{array}{c}0.081 \\
(0.097)\end{array}$ \\
\hline 1st Gen. Age at Immigration > 20 & $\begin{array}{c}-0.248^{* * *} \\
(0.067)\end{array}$ & $\begin{array}{c}-0.155^{* * *} \\
(0.039)\end{array}$ & $\begin{array}{c}-0.135^{* * *} \\
(0.031)\end{array}$ & $\begin{array}{c}-0.177 * * * \\
(0.042)\end{array}$ & $\begin{array}{c}-0.175^{* * *} \\
(0.051)\end{array}$ \\
\hline Observations & 21,055 & 32,649 & 32,288 & 14,513 & 6,990 \\
\hline R-squared & 0.05 & 0.07 & 0.07 & 0.15 & 0.15 \\
\hline & $\begin{array}{c}\text { Less than } \\
\text { High School }\end{array}$ & $\begin{array}{c}\text { (B) Mother Tol } \\
\text { High School } \\
\text { Graduates }\end{array}$ & $\begin{array}{l}\text { Igue is Non-Offi } \\
\text { Some } \\
\text { Postsecondary }\end{array}$ & $\begin{array}{l}\text { ial Language } \\
\text { Bachelor's } \\
\text { Degree }\end{array}$ & Postgraduate \\
\hline 3rd+ Gen. & $\begin{array}{c}-0.339 * * * \\
(0.065)\end{array}$ & $\begin{array}{c}-0.331^{* * * *} \\
(0.048)\end{array}$ & $\begin{array}{c}-0.221 * * * \\
(0.044)\end{array}$ & $\begin{array}{c}-0.126^{* *} \\
(0.061)\end{array}$ & $\begin{array}{c}-0.209 * * \\
(0.087)\end{array}$ \\
\hline 2nd Gen. Father Foreign Born & $\begin{array}{l}-0.193 \\
(0.157)\end{array}$ & $\begin{array}{l}-0.200^{*} \\
(0.107)\end{array}$ & $\begin{array}{l}-0.071 \\
(0.092)\end{array}$ & $\begin{array}{l}-0.175 \\
(0.129)\end{array}$ & $\begin{array}{l}-0.275 \\
(0.194)\end{array}$ \\
\hline 2nd Gen. Mother Foreign Born & $\begin{array}{c}0.014 \\
(0.174)\end{array}$ & $\begin{array}{c}-0.343^{* * *} \\
(0.104)\end{array}$ & $\begin{array}{l}-0.134 \\
(0.102)\end{array}$ & $\begin{array}{l}-0.149 \\
(0.141)\end{array}$ & $\begin{array}{c}0.003 \\
(0.215)\end{array}$ \\
\hline 1st Gen. Age at Immigration 0-4 & $\begin{array}{l}-0.134 \\
(0.100)\end{array}$ & $\begin{array}{c}0.007 \\
(0.062)\end{array}$ & $\begin{array}{l}-0.050 \\
(0.056)\end{array}$ & $\begin{array}{c}0.012 \\
(0.074)\end{array}$ & $\begin{array}{c}0.010 \\
(0.109)\end{array}$ \\
\hline 1st Gen. Age at Immigration 5-12 & $\begin{array}{c}0.012 \\
(0.073)\end{array}$ & $\begin{array}{l}-0.055 \\
(0.052)\end{array}$ & $\begin{array}{c}-0.135^{* * *} \\
(0.048)\end{array}$ & $\begin{array}{c}0.036 \\
(0.060)\end{array}$ & $\begin{array}{l}-0.007 \\
(0.096)\end{array}$ \\
\hline 1st Gen. Age at Immigration 13-19 & $\begin{array}{c}0.028 \\
(0.067)\end{array}$ & $\begin{array}{c}-0.129 * * * \\
(0.050)\end{array}$ & $\begin{array}{c}-0.139 * * * \\
(0.048)\end{array}$ & $\begin{array}{l}-0.095 \\
(0.061)\end{array}$ & $\begin{array}{c}0.004 \\
(0.097)\end{array}$ \\
\hline 1st Gen. Age at Immigration $>20$ & $\begin{array}{c}-0.192 * * * \\
(0.062)\end{array}$ & $\begin{array}{c}-0.313^{* * *} \\
(0.042)\end{array}$ & $\begin{array}{c}-0.445^{* * *} \\
(0.037)\end{array}$ & $\begin{array}{c}-0.601^{* * *} \\
(0.046)\end{array}$ & $\begin{array}{c}-0.453^{* * *} \\
(0.063)\end{array}$ \\
\hline Observations & 7,896 & 9,240 & 9,356 & 5,906 & 3,866 \\
\hline R-squared & 0.06 & 0.08 & 0.08 & 0.12 & 0.08 \\
\hline
\end{tabular}

NOTES: Standard errors are in parentheses. Significance levels are indicated by * for $10 \%,{ }^{* *}$ for $5 \%$, and $* * *$ for $1 \%$. The dependent variable is the logarithm of annual wages. Regressions control for age, marital status, visible minority status and CMA. The sample is restricted to non-aboriginal males aged 25-54 who have positive wages. 
Table 6

Regression Results of Wage Function of Males by Education and CMA: Immigrant Generation

\begin{tabular}{|c|c|c|c|c|c|}
\hline & \multicolumn{5}{|c|}{ (A) Toronto } \\
\hline & $\begin{array}{l}\text { Less than } \\
\text { High School }\end{array}$ & $\begin{array}{c}\text { High School } \\
\text { Graduates }\end{array}$ & $\begin{array}{c}\text { Some } \\
\text { Postsecondary }\end{array}$ & $\begin{array}{l}\text { Bachelor's } \\
\text { Degree }\end{array}$ & Postgraduate \\
\hline 3rd+ Gen. & $\begin{array}{l}-0.030 \\
(0.067)\end{array}$ & $\begin{array}{l}-0.011 \\
(0.040)\end{array}$ & $\begin{array}{l}-0.066 * \\
(0.038)\end{array}$ & $\begin{array}{l}-0.019 \\
(0.045)\end{array}$ & $\begin{array}{l}-0.080 \\
(0.071)\end{array}$ \\
\hline 2nd Gen. Father Foreign Born & $\begin{array}{c}0.013 \\
(0.126)\end{array}$ & $\begin{array}{l}-0.027 \\
(0.070)\end{array}$ & $\begin{array}{l}-0.136 * \\
(0.070)\end{array}$ & $\begin{array}{l}-0.049 \\
(0.075)\end{array}$ & $\begin{array}{l}-0.069 \\
(0.118)\end{array}$ \\
\hline 2nd Gen. Mother Foreign Born & $\begin{array}{c}0.044 \\
(0.134)\end{array}$ & $\begin{array}{l}-0.032 \\
(0.079)\end{array}$ & $\begin{array}{l}-0.037 \\
(0.074)\end{array}$ & $\begin{array}{l}-0.151^{*} \\
(0.083)\end{array}$ & $\begin{array}{l}-0.027 \\
(0.123)\end{array}$ \\
\hline 1st Gen. Age at Immigration 0-4 & $\begin{array}{c}0.071 \\
(0.127)\end{array}$ & $\begin{array}{l}-0.006 \\
(0.071)\end{array}$ & $\begin{array}{l}-0.012 \\
(0.069)\end{array}$ & $\begin{array}{c}0.081 \\
(0.079)\end{array}$ & $\begin{array}{c}0.139 \\
(0.123)\end{array}$ \\
\hline 1st Gen. Age at Immigration 5-12 & $\begin{array}{c}0.104 \\
(0.092)\end{array}$ & $\begin{array}{c}0.062 \\
(0.061)\end{array}$ & $\begin{array}{l}-0.022 \\
(0.059)\end{array}$ & $\begin{array}{l}0.131^{*} \\
(0.068)\end{array}$ & $\begin{array}{c}0.053 \\
(0.114)\end{array}$ \\
\hline 1st Gen. Age at Immigration 13-19 & $\begin{array}{c}0.028 \\
(0.083)\end{array}$ & $\begin{array}{l}-0.102^{*} \\
(0.058)\end{array}$ & $\begin{array}{l}-0.078 \\
(0.058)\end{array}$ & $\begin{array}{c}0.015 \\
(0.070)\end{array}$ & $\begin{array}{c}0.103 \\
(0.114)\end{array}$ \\
\hline 1st Gen. Age at Immigration $>20$ & $\begin{array}{l}-0.097 \\
(0.077)\end{array}$ & $\begin{array}{c}-0.229 * * * \\
(0.050)\end{array}$ & $\begin{array}{c}-0.290 * * * \\
(0.045)\end{array}$ & $\begin{array}{c}-0.463^{* * *} \\
(0.052)\end{array}$ & $\begin{array}{c}-0.456^{* * * *} \\
(0.074)\end{array}$ \\
\hline $\begin{array}{l}\text { Observations } \\
\text { R-squared }\end{array}$ & $\begin{array}{c}3,968 \\
0.07 \\
\end{array}$ & $\begin{array}{c}6,011 \\
0.10 \\
\end{array}$ & $\begin{array}{c}6,206 \\
0.09\end{array}$ & $\begin{array}{c}4,817 \\
0.17 \\
\end{array}$ & $\begin{array}{c}2,811 \\
0.16 \\
\end{array}$ \\
\hline & $\begin{array}{l}\text { Less than } \\
\text { High School }\end{array}$ & $\begin{array}{l}\text { High School } \\
\text { Graduates }\end{array}$ & $\begin{array}{l}\text { (B) Vancouver } \\
\text { Some } \\
\text { Postsecondary }\end{array}$ & $\begin{array}{l}\text { Bachelor's } \\
\text { Degree }\end{array}$ & Postgraduate \\
\hline 3rd+ Gen. & $\begin{array}{l}-0.121 \\
(0.104)\end{array}$ & $\begin{array}{l}-0.024 \\
(0.066)\end{array}$ & $\begin{array}{l}-0.035 \\
(0.060)\end{array}$ & $\begin{array}{l}-0.068 \\
(0.079)\end{array}$ & $\begin{array}{l}-0.041 \\
(0.119)\end{array}$ \\
\hline 2nd Gen. Father Foreign Born & $\begin{array}{c}0.028 \\
(0.153)\end{array}$ & $\begin{array}{c}0.056 \\
(0.100)\end{array}$ & $\begin{array}{c}0.108 \\
(0.089)\end{array}$ & $\begin{array}{l}-0.046 \\
(0.115)\end{array}$ & $\begin{array}{l}-0.144 \\
(0.186)\end{array}$ \\
\hline 2nd Gen. Mother Foreign Born & $\begin{array}{l}-0.177 \\
(0.162)\end{array}$ & $\begin{array}{l}-0.084 \\
(0.107)\end{array}$ & $\begin{array}{l}-0.131 \\
(0.104)\end{array}$ & $\begin{array}{l}-0.052 \\
(0.123)\end{array}$ & $\begin{array}{l}-0.312 \\
(0.208)\end{array}$ \\
\hline 1st Gen. Age at Immigration 0-4 & $\begin{array}{c}0.193 \\
(0.268)\end{array}$ & $\begin{array}{c}0.095 \\
(0.127)\end{array}$ & $\begin{array}{c}0.142 \\
(0.118)\end{array}$ & $\begin{array}{l}-0.010 \\
(0.130)\end{array}$ & $\begin{array}{c}0.037 \\
(0.276)\end{array}$ \\
\hline 1st Gen. Age at Immigration 5-12 & $\begin{array}{c}0.102 \\
(0.171)\end{array}$ & $\begin{array}{c}0.045 \\
(0.101)\end{array}$ & $\begin{array}{l}-0.115 \\
(0.100)\end{array}$ & $\begin{array}{c}0.340 * * * \\
(0.114)\end{array}$ & $\begin{array}{c}0.128 \\
(0.196)\end{array}$ \\
\hline 1st Gen. Age at Immigration 13-19 & $\begin{array}{c}0.147 \\
(0.159)\end{array}$ & $\begin{array}{c}0.007 \\
(0.104)\end{array}$ & $\begin{array}{c}0.045 \\
(0.096)\end{array}$ & $\begin{array}{l}-0.131 \\
(0.115)\end{array}$ & $\begin{array}{c}0.022 \\
(0.203)\end{array}$ \\
\hline 1st Gen. Age at Immigration $>20$ & $\begin{array}{l}-0.190 \\
(0.137)\end{array}$ & $\begin{array}{c}-0.237^{* * *} \\
(0.084)\end{array}$ & $\begin{array}{c}-0.243^{* * *} \\
(0.071)\end{array}$ & $\begin{array}{c}-0.469 * * * \\
(0.085)\end{array}$ & $\begin{array}{c}-0.329 * * * \\
(0.120)\end{array}$ \\
\hline Observations & 1,598 & 2,511 & 2,850 & 1,802 & 976 \\
\hline R-squared & 0.08 & 0.12 & 0.12 & 0.20 & 0.14 \\
\hline
\end{tabular}


Table 6 (continued)

\begin{tabular}{|c|c|c|c|c|c|}
\hline & $\begin{array}{l}\text { Less than } \\
\text { High School }\end{array}$ & $\begin{array}{l}\text { High School } \\
\text { Graduates }\end{array}$ & $\begin{array}{l}\text { (C) Montreal } \\
\text { Some } \\
\text { Postsecondary }\end{array}$ & $\begin{array}{l}\text { Bachelor's } \\
\text { Degree }\end{array}$ & Postgraduate \\
\hline 3rd+ Gen. & $\begin{array}{l}-0.126 \\
(0.134)\end{array}$ & $\begin{array}{c}0.068 \\
(0.074)\end{array}$ & $\begin{array}{c}0.088 \\
(0.061)\end{array}$ & $\begin{array}{l}-0.002 \\
(0.072)\end{array}$ & $\begin{array}{l}-0.180 \\
(0.114)\end{array}$ \\
\hline 2nd Gen. Father Foreign Born & $\begin{array}{c}-0.590 * * * \\
(0.212)\end{array}$ & $\begin{array}{l}-0.094 \\
(0.124)\end{array}$ & $\begin{array}{c}0.063 \\
(0.098)\end{array}$ & $\begin{array}{l}-0.005 \\
(0.121)\end{array}$ & $\begin{array}{l}-0.128 \\
(0.180)\end{array}$ \\
\hline 2nd Gen. Mother Foreign Born & $\begin{array}{l}-0.008 \\
(0.253)\end{array}$ & $\begin{array}{l}-0.036 \\
(0.148)\end{array}$ & $\begin{array}{c}0.142 \\
(0.130)\end{array}$ & $\begin{array}{c}0.055 \\
(0.151)\end{array}$ & $\begin{array}{l}-0.376^{*} \\
(0.212)\end{array}$ \\
\hline 1st Gen. Age at Immigration 0-4 & $\begin{array}{l}-0.003 \\
(0.285)\end{array}$ & $\begin{array}{c}0.248 \\
(0.154)\end{array}$ & $\begin{array}{c}0.128 \\
(0.115)\end{array}$ & $\begin{array}{l}-0.216 \\
(0.146)\end{array}$ & $\begin{array}{l}-0.280 \\
(0.232)\end{array}$ \\
\hline 1st Gen. Age at Immigration 5-12 & $\begin{array}{l}-0.280 \\
(0.175)\end{array}$ & $\begin{array}{l}-0.159 \\
(0.117)\end{array}$ & $\begin{array}{l}-0.118 \\
(0.096)\end{array}$ & $\begin{array}{c}0.174 \\
(0.124)\end{array}$ & $\begin{array}{c}-0.272 \\
(0.172)\end{array}$ \\
\hline 1st Gen. Age at Immigration 13-19 & $\begin{array}{c}-0.356^{* *} \\
(0.160)\end{array}$ & $\begin{array}{l}-0.067 \\
(0.117)\end{array}$ & $\begin{array}{l}-0.156 \\
(0.097)\end{array}$ & $\begin{array}{c}0.138 \\
(0.121)\end{array}$ & $\begin{array}{l}-0.100 \\
(0.193)\end{array}$ \\
\hline 1st Gen. Age at Immigration >20 & $\begin{array}{c}-0.458 * * * \\
(0.139)\end{array}$ & $\begin{array}{l}-0.150^{*} \\
(0.086)\end{array}$ & $\begin{array}{c}-0.385 * * * \\
(0.072)\end{array}$ & $\begin{array}{c}-0.568 * * * \\
(0.083)\end{array}$ & $\begin{array}{c}-0.365^{* * *} \\
(0.115)\end{array}$ \\
\hline $\begin{array}{l}\text { Observations } \\
\text { R-squared }\end{array}$ & $\begin{array}{c}2,967 \\
0.07\end{array}$ & $\begin{array}{l}4,641 \\
0.092 \\
\end{array}$ & $\begin{array}{c}5,084 \\
0.12 \\
\end{array}$ & $\begin{array}{c}2,736 \\
0.17\end{array}$ & $\begin{array}{c}1,497 \\
0.12 \\
\end{array}$ \\
\hline & $\begin{array}{l}\text { Less than } \\
\text { High School }\end{array}$ & $\begin{array}{l}\text { High School } \\
\text { Graduates }\end{array}$ & $\begin{array}{l}\text { (D) Other CMA } \\
\text { Some } \\
\text { Postsecondary }\end{array}$ & $\begin{array}{l}\text { Bachelor's } \\
\text { Degree }\end{array}$ & Postgraduate \\
\hline 3rd+ Gen. & $\begin{array}{l}-0.005 \\
(0.055)\end{array}$ & $\begin{array}{l}-0.063^{*} \\
(0.033)\end{array}$ & $\begin{array}{c}-0.083^{* * *} \\
(0.029)\end{array}$ & $\begin{array}{l}-0.055 \\
(0.041)\end{array}$ & $\begin{array}{l}-0.046 \\
(0.056)\end{array}$ \\
\hline 2nd Gen. Father Foreign Born & $\begin{array}{l}-0.107 \\
(0.081)\end{array}$ & $\begin{array}{l}-0.058 \\
(0.048)\end{array}$ & $\begin{array}{l}-0.028 \\
(0.044)\end{array}$ & $\begin{array}{l}-0.063 \\
(0.059)\end{array}$ & $\begin{array}{l}-0.038 \\
(0.088)\end{array}$ \\
\hline 2nd Gen. Mother Foreign Born & $\begin{array}{c}0.020 \\
(0.087)\end{array}$ & $\begin{array}{l}-0.070 \\
(0.052)\end{array}$ & $\begin{array}{c}-0.109 * * \\
(0.047)\end{array}$ & $\begin{array}{c}-0.153^{* *} \\
(0.067)\end{array}$ & $\begin{array}{l}-0.073 \\
(0.088)\end{array}$ \\
\hline 1st Gen. Age at Immigration 0-4 & $\begin{array}{l}-0.001 \\
(0.110)\end{array}$ & $\begin{array}{c}-0.052 \\
(0.066)\end{array}$ & $\begin{array}{c}-0.092 \\
(0.060)\end{array}$ & $\begin{array}{l}-0.041 \\
(0.079)\end{array}$ & $\begin{array}{l}-0.017 \\
(0.108)\end{array}$ \\
\hline 1st Gen. Age at Immigration 5-12 & $\begin{array}{c}0.127 \\
(0.090)\end{array}$ & $\begin{array}{c}-0.063 \\
(0.060)\end{array}$ & $\begin{array}{l}-0.036 \\
(0.054)\end{array}$ & $\begin{array}{l}-0.011 \\
(0.071)\end{array}$ & $\begin{array}{l}-0.023 \\
(0.100)\end{array}$ \\
\hline 1st Gen. Age at Immigration 13-19 & $\begin{array}{l}0.161^{*} \\
(0.091)\end{array}$ & $\begin{array}{l}-0.046 \\
(0.063)\end{array}$ & $\begin{array}{l}-0.025 \\
(0.059)\end{array}$ & $\begin{array}{l}-0.003 \\
(0.083)\end{array}$ & $\begin{array}{c}0.147 \\
(0.113)\end{array}$ \\
\hline 1st Gen. Age at Immigration $>20$ & $\begin{array}{l}-0.110 \\
(0.080)\end{array}$ & $\begin{array}{c}-0.293 * * * \\
(0.049)\end{array}$ & $\begin{array}{c}-0.284 * * * \\
(0.040)\end{array}$ & $\begin{array}{c}-0.401^{* * *} \\
(0.056)\end{array}$ & $\begin{array}{c}-0.256 * * * \\
(0.065)\end{array}$ \\
\hline Observations & 7,449 & 12,356 & 12,982 & 6,796 & 3,580 \\
\hline R-squared & 0.07 & 0.09 & 0.09 & 0.16 & 0.14 \\
\hline
\end{tabular}


Table 6 (continued)

\begin{tabular}{lccccc}
\hline & & & (E) Non-CMA & \\
& $\begin{array}{l}\text { Less than } \\
\text { High School }\end{array}$ & $\begin{array}{l}\text { High School } \\
\text { Graduates }\end{array}$ & $\begin{array}{l}\text { Some } \\
\text { Postsecondary }\end{array}$ & $\begin{array}{l}\text { Bachelor's } \\
\text { Degree }\end{array}$ & Postgraduate \\
\cline { 2 - 6 } & & & & & \\
3rd+ Gen. & -0.048 & 0.008 & -0.031 & 0.085 & -0.065 \\
& $(0.056)$ & $(0.041)$ & $(0.036)$ & $(0.061)$ & $(0.087)$ \\
2nd Gen. Father Foreign Born & -0.025 & -0.015 & -0.029 & 0.082 & -0.053 \\
& $(0.077)$ & $(0.056)$ & $(0.051)$ & $(0.081)$ & $(0.134)$ \\
2nd Gen. Mother Foreign Born & 0.032 & 0.035 & -0.051 & -0.026 & -0.056 \\
& $(0.080)$ & $(0.058)$ & $(0.053)$ & $(0.085)$ & $(0.131)$ \\
1st Gen. Age at Immigration 0-4 & -0.068 & 0.060 & -0.109 & $0.265 * *$ & -0.038 \\
& $(0.129)$ & $(0.085)$ & $(0.075)$ & $(0.120)$ & $(0.162)$ \\
1st Gen. Age at Immigration 5-12 & -0.064 & -0.040 & $-0.128 *$ & 0.137 & -0.038 \\
& $(0.105)$ & $(0.077)$ & $(0.072)$ & $(0.111)$ & $(0.171)$ \\
1st Gen. Age at Immigration 13-19) & 0.135 & 0.134 & -0.134 & 0.097 & 0.349 \\
& $(0.118)$ & $(0.095)$ & $(0.085)$ & $(0.142)$ & $(0.217)$ \\
1st Gen. Age at Immigration $>20$ & $-0.215 * *$ & $-0.164 * *$ & $-0.249 * * *$ & -0.088 & -0.127 \\
& $(0.095)$ & $(0.071)$ & $(0.057)$ & $(0.084)$ & $(0.105)$ \\
Observations & & & & & \\
R-squared & 12,969 & 16,370 & 14,522 & 4,268 & 1,992 \\
\hline
\end{tabular}

NOTES: Standard errors are in parentheses. Significance levels are indicated by $*$ for $10 \%$, $* *$ for $5 \%$, and $* * *$ for $1 \%$. The dependent variable is the logarithm of annual wages. Regressions control for age, mother tongue, marital status, visible minority status and province. The sample is restricted to non-aboriginal males aged 25-54 who have positive wages. 